\title{
TIM RaDar as a Practical Screening Tool for IMRaD Articles: Consensual Publication Standards Among Indonesian Psychological Journal Editors
}

\section{TIM RaDar Sebagai Alat Screening Praktis untuk Artikel IMRaD: Standar Publikasi Konsensual Bagi Editor Jurnal Psikologi Indonesia}

\author{
Edwin Adrianta Surijah \\ Faculty of Health, School of Psychology and Counselling \\ Queensland University of Technology (QUT)
}

School of Psychology
Universitas Dhyana Pura

Juneman Abraham

Jurusan Psikologi, Fakultas Humaniora

Universitas Bina Nusantara

Himpunan Psikologi Indonesia (HIMPSI)

\section{Christiany Suwartono}

Fakultas Psikologi \& Pusat Unggulan Kebijakan Kesehatan dan Inovasi Sosial (PUI-PT PPH) Universitas Katolik Indonesia Atma Jaya

\author{
Ide Bagus Siaputra \\ Fakultas Psikologi \\ Universitas Surabaya
}

TIM RaDaR is an initiative to discover common standards for scientific publications in the field of psychology in Indonesia. Through this standard, authors (i.e., researchers, students, or lecturers) may prepare their manuscripts to meet the basic criteria for scientific publication. The writing criteria comprise of Title, Introduction, Methods, Results and Discussion, and References. This article also provides a checklist to aid authors and journal editors in evaluating manuscripts to be published. As an initiative, this article aims to become a starting point in synergizing better quality scientific publications in the field of psychology in Indonesia.

Keywords: article, scientific writing, guideline

TIM RaDaR adalah sebuah inisiatif untuk menggali standar bersama publikasi ilmiah psikologi Indonesia. Melalui standar ini, penulis (peneliti, mahasiswa, atau dosen) dapat mempersiapkan tulisan yang mereka susun untuk memenuhi kriteria dasar publikasi ilmiah. Kriteria tersebut mencakup penulisan Judul, Pendahuluan, Metode, Hasil dan Diskusi, serta Pustaka Acuan (Title, Introduction, Methods, Results and Discussion, and References). Tulisan ini juga memberikan sebuah checklist yang dapat digunakan sebagai alat bantu bagi penulis dan pengelola jurnal untuk mengevaluasi tulisan yang telah disusun. Sebagai suatu inisiatif, tulisan ini menjadi titik awal sinergi publikasi ilmiah psikologi Indonesia yang lebih bermutu di masa mendatang.

Kata kunci: artikel, karya ilmiah, panduan
Received/Masuk:
27 February/Februari 2021
Accepted/Terima:
Published/Terbit:
14 July/Juli 2021
25 July/Juli 2021 


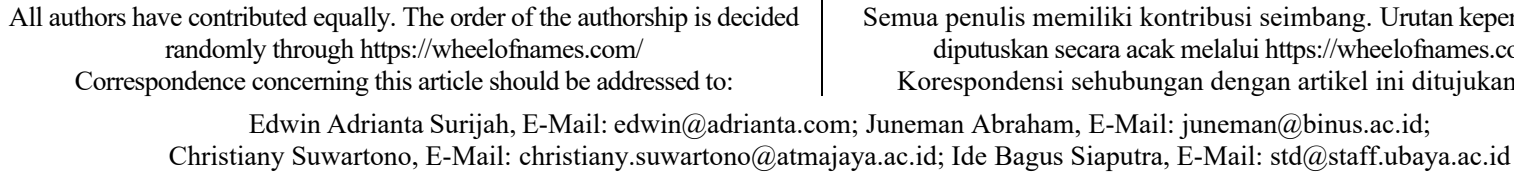

The writing of research reports or scientific papers has had many complete and holistic guidelines. In the official website of Enhancing the QUAlity and Transparency Of health Research (EQUATOR Network; n.d.), a large number of reporting guidelines have been made available, including reporting guidelines on 40 different research topics (e.g., allergy, palliative care, psychiatry, psychology, etc.), 13 different types of research (e.g., experimental research, observational research, literature studies, etc.), and 25 different sections of scientific articles (e.g., abstract, data, title, method, etc.). Several reporting guidelines have become immensely popular with over 10,000 Google Scholar citations, e.g., Strengthening the Reporting of Observational Studies in Epidemiology (STROBE; von Elm et al., 2007), Consolidated Standards of Reporting Trials (CONSORT; Schulz et al., 2010a; 2010b), and Preferred Reporting Items for Systematic Review and Meta-Analysis Protocols (PRISMA-P; Shamseer et al., 2014). In 2021, Preferred Reporting Items for Systematic Review and Meta-Analysis Protocols (PRISMA-P) has been updated to its latest version with detailed checklist and flow-chart to improve transparency and comprehensiveness in reporting systematic studies (Page et al., 2021).

Specific to the field of psychology, the term "reporting guideline" has been introduced since 1999 by the British Psychological Society (BPS; Elliot et al., 1999) to provide a benchmark for reporting qualitative studies. Additionally, in 2008 the American Pychological Association (APA) also introduced guidelines for research reports in the form of Journal Article Reporting Standards (JARS; American Psychological Association [APA] Publi-cations and Communications Board Working Group on Journal Article Reporting Standards [JARS], 2008). The latter has been revised over the years have been integrated into the American Psychological Association (APA) Publication Manual, Seventh Edition (American Psychological Association [APA], 2020; Kazak, 2018), which has become one of the main references for many international publications particularly in the domain of psychology. Since 2018, the Journal
Sejatinya, penulisan laporan hasil penelitian atau karya ilmiah telah memiliki banyak panduan yang dibuat dengan sangat komplit dan menyeluruh. Dalam website resmi Enhancing the QUAlity and Transparency Of health Research (EQUATOR Network; n.d.), telah ada sejumlah besar reporting guideline, termasuk di antaranya panduan pelaporan untuk 40 topik penelitian (contoh: alergi, layanan paliatif, psikiatri, psikologi, dan lain-lain), 13 jenis penelitian (contoh: eksperimen, observasi, telaah literatur, dan lain-lain), dan 25 bagian pada sebuah artikel (contoh: abstrak, data, judul, metode, dan-lain-lain). Beberapa reporting guideline telah sangat terkenal dan memiliki riwayat pengutipan di Google Scholar sebanyak lebih dari 10.000 kali, sebagai contoh adalah Strengthening the Reporting of Observational Studies in Epidemiology (STROBE; von Elm et al., 2007), Consolidated Standards of Reporting Trials (CONSORT; Schulz et al., 2010a; 2010b), Preferred Reporting Items for Systematic Review and Meta-Analysis Protocols (PRISMA-P; Shamseer et al., 2015). Pada 2021, Preferred Reporting Items for Systematic Review and Meta-Analysis Protocols (PRISMA-P) telah dimutakhirkan menjadi versi terbaru dengan daftar periksa dan diagram alir yang lebih rinci demi meningkatkan transparansi dan kelengkapan pelaporan telaah sistematik (Page et al., 2021).

Secara spesifik di bidang psikologi, istilah "reporting guideline" telah diperkenalkan sejak 1999 oleh British Psychological Society (BPS; Elliot et al., 1999) untuk memberikan panduan dalam melaporkan penelitian kualitatif. Selain itu, sejak 2008 American Pychological Association (APA) juga memperkenalkan panduan pelaporan penelitian berupa Journal Article Reporting Standards (JARS; American Psychological Association [APA] Publications and Communications Board Working Group on Journal Article Reporting Standards [JARS], 2008). Pedoman ini terus disempurnakan dan diintegrasikan dalam American Psychological Association (APA) Publication Manual Edisi ke-7 (American Psychological Association [APA], 2020; Kazak, 2018) yang menjadi suatu acuan utama bagi banyak publikasi ilmiah internasional khususnya di ranah psikologi. Sejak 2018, Journal Article Reporting Standards 
Article Reporting Standards (JARS) have been designed more uniquely and specifically for various types of quantitative research (Appelbaum et al., 2018; Cooper, 2020), as well as for studies with qualitative approach and mixed methods (Levitt et al., 2018; Levitt, 2020).

In addition to the well-known and widely recommended guidelines, editors of each journal have also provided authors' guidelines specific to their respective journals. In the formal education settings, courses on scientific writing or research proposals have provided various sources of information beneficial for scholars and scientists in the field psychology. With so many available information, this study is not aimed towards "teaching fish how to swim" (Latin: "piscem natare doces"). Meaning, we believe that our readers are proficient writers, and that there are far superior reference sources than what we have written in this Editorial. However, this Editorial is our initiative that began with a symposium of Indonesian psychological journal editors on August 5,2020 . This meeting was designed to capture the difficulties faced by journal editors, and to formulate strategic steps necessary to increase the speed and quality of psychological publications in Indonesia. One of the agreed upon points is the consensus on the minimum content standards on research report writing in Indonesian psychological journals.

The minimum content standards for scientific publications in the domain of psychology in Indonesia is abbreviated as "TIM RaDaR" (Title, Introduction, Method, Result, Discussion, and References). This acronym was formulated as a neutral term that can be easily read in both Bahasa Indonesia and English, to indicate the closeness of this consensual publication standards to the universal format commonly used in scientific publications, widely known as "IMRaD" (Introduction, Methods, Results, and Discussion). For psychology scientists, students, and would-be authors/contributors, TIM RaDaR aims to provide a concise and easy-to-understand information on the minimum content standards of a scientific article, and not limited to any specific journal's house style guide. For editors of psychological journals in Indonesia, TIM RaDaR aims to help increase the quality standards of submitted manuscripts, such that the incoming articles would at least meet the initial criteria for desk review. For lecturers or educators
(JARS) telah dirancang secara makin unik dan spesifik untuk beragam pelaporan hasil penelitian di bidang kuantitatif (Appelbaum et al., 2018; Cooper, 2020) serta kualitatif dan metode campuran (Levitt et al., 2018; Levitt, 2020).

Selain berbagai pedoman yang dikenal dan direkomendasikan secara luas, tiap pengelola jurnal juga telah memberikan panduan bagi penulis yang menjadi panduan khas di jurnal tersebut. Pada ranah pendidikan formal, kelas atau matakuliah penulisan karya ilmiah atau proposal penelitian telah menyediakan beragam sumber informasi yang bermanfaat bagi para pembelajar dan ilmuwan psikologi. Dengan begitu banyaknya informasi yang telah tersedia, tulisan ini tidak hendak "mengajari ikan berenang" (Latin: "piscem nature doces"). Artinya, kami meyakini bahwa para pembaca sekalian telah pandai menulis serta ada banyak sumber jauh yang lebih baik daripada apa yang kami tuangkan dalam Editorial kali ini. Akan tetapi, Editorial kali ini adalah inisiatif kami yang bermula dari pertemuan yang dihadiri pengelola jurnal psikologi di Indonesia pada 5 Agustus 2020. Pertemuan tersebut menjaring kesulitan apa saja yang dihadapi para pengelola dan menghasilkan suatu rumusan langkah strategis apa yang dapat ditempuh untuk meningkatkan kecepatan dan kualitas publikasi psikologi di Indonesia. Salah satu poin yang disepakati adalah kesepakatan standar isi minimal suatu tulisan laporan hasil penelitian di jurnal psikologi di Indonesia.

Standar minimal isi publikasi ilmiah psikologi di Indonesia kami sebut dengan akronim "TIM RaDaR" (Title, Introduction, Method, Result, Discussion, and References). Akronim ini dibuat dalam istilah netral yang dapat dibaca dalam Bahasa Indonesia dan Bahasa Inggris, untuk menunjukkan kedekatan hasil kesepakatan ini dengan format universal yang lazim dipakai dalam publikasi ilmiah yang kerap dikenal dengan "IMRaD" (Introduction, Methods, Results, and Discussion). Bagi ilmuwan psikologi, mahasiswa, dan calon kontributor/penulis, TIM $\mathrm{RaDaR}$ ditujukan sebagai informasi ringkas yang mudah dipahami terkait standar minimal isi suatu artikel dan tidak terbatas pada satu gaya selingkung jurnal tertentu. Bagi pengelola jurnal psikologi di Indonesia, TIM RaDaR ditujukan membantu meningkatkan standar mutu artikel yang masuk di dapur redaksi sehingga artikel tersebut sekurang-kurangnya telah memenuhi kriteria awal proses desk review. Bagi pengajar atau tenaga pendidik yang mengampu 
who teach courses related to the learning outcomes of scientific writing, TIM RaDaR aims to help formulate the instructional objectives or lesson plans. The concise information of TIM RaDaR is presented in the form of a table (see Table 1), which can be reprinted and shared openly (CC-BY license) to broaden its benefits. Detailed description of TIM RaDaR is further elaborated in the following sections. capaian pembelajaran terkait penulisan karya ilmiah, TIM RaDaR ditujukan untuk membantu merumuskan tinjauan instruksional atau rencana pembelajaran. Informasi ringkas TIM RaDaR disajikan dalam bentuk tabel (tersedia dalam Tabel 1), yang dapat dicetak ulang dan dibagikan (lisensi CC-BY) sehingga meningkatkan kebermanfaatan seluas-luasnya. Secara lebih detil, berikut adalah uraian mendalam tentang TIM RaDaR.

\section{Table 1}

TIM RaDaR: Recommended Checklist for the Minimum Information in an Article

\begin{tabular}{|c|c|c|c|}
\hline No. & $\begin{array}{l}\text { Section of } \\
\text { Article }\end{array}$ & Criteria & $\begin{array}{l}\text { Reported } \\
\text { in Page: }\end{array}$ \\
\hline 1 & Title 1 & The article title has identified the variables & \\
\hline 2 & Title 2 & The article title has identified the theoretical issues being researched or studied & \\
\hline 3 & Introduction 1 & Introduction: The problem statement is clearly stated & \\
\hline 4 & Introduction 2 & $\begin{array}{l}\text { Introduction: The purpose of the study is clearly stated (theoretical and } \\
\text { applied/practical) }\end{array}$ & \\
\hline 5 & Introduction 3 & Study of relevant research: The connection with previous research (novelty and merit) & \\
\hline 6 & Method 1 & $\begin{array}{l}\text { Research design, or paradigm, (quantitative, qualitative, mixed methods, or } \\
\text { literature study) }\end{array}$ & \\
\hline 7 & Method 2 & $\begin{array}{l}\text { Research participants (procedures of data sampling, participant criteria, population, } \\
\text { sample) }\end{array}$ & \\
\hline 8 & Method 3 & Data collection methods (interviews, observations, instruments) & \\
\hline 9 & Result 1 & Inclusion of effect size (coefficient, correlation, regression) for quantitative research & \\
\hline 10 & Result 2 & $\begin{array}{l}\text { Results: report the demographic analysis or descriptive analysis relevant to the } \\
\text { purpose of the research }\end{array}$ & \\
\hline 11 & Discussion 1 & Discussion: Statements supporting or not supporting the research hypotheses & \\
\hline 12 & Discussion 2 & $\begin{array}{l}\text { Discussion: similarity and differences between this research results with previous } \\
\text { studies }\end{array}$ & \\
\hline 13 & Discussion 2 & Research conclusion (impact/external validity; answering the research questions) & \\
\hline 14 & Reference 1 & References: most citations refer to journal articles & \\
\hline 15 & Reference 2 & More than $80 \%$ of the references are current up to ten years & \\
\hline
\end{tabular}

\section{T for Title}

A "Title" of a scientific article is analogous to a cover to the book it binds. "Title" is the face (Tullu, 2019) or gate (Bavdekar, 2016) that creates the first impression in the minds of the readers. The "Title" is often the first (if not the only) thing that the audience read. It becomes the basis for consideration whether or not to continue reading an article. This is a universal notion for all types of readers, from students, scholars, reviewers, to editors. A "bad" "Title" could easily be ignored, or at least overlooked by readers.

\section{Tentang Judul}

"Judul" pada sebuah artikel ilmiah dapat diibaratkan sebagai sampul pada sebuah buku. "Judul" merupakan wajah (Tullu, 2019) atau gerbang (Bavdekar, 2016) yang memunculkan kesan pertama dalam diri pembaca. "Judul" seringkali menjadi hal pertama (bahkan tidak jarang menjadi satu-satunya bagian) yang dibaca oleh pembaca. "Judul" menjadi dasar pertimbangan untuk membaca dan menilai isi suatu artikel. Hal ini berlaku universal bagi segala macam pembaca, mulai dari mahasiswa, ilmuwan, mitra bestari, hingga penyunting jurnal. "Judul" yang "buruk" dapat dengan mudah diabaikan atau setidaknya dilewatkan pembaca. 
Tabel 1

TIM RaDaR: Daftar Periksa yang Direkomendasikan Perihal Informasi Minimum dalam Artikel

\begin{tabular}{|c|c|c|c|}
\hline No. & $\begin{array}{l}\text { Bagian Dalam } \\
\text { Artikel }\end{array}$ & Kriteria & $\begin{array}{l}\text { Dilaporkan } \\
\text { di Halaman: }\end{array}$ \\
\hline 1 & Judul 1 & Judul artikel telah mengidentifikasi variabel & \\
\hline 2 & Judul 2 & Judul artikel telah mengidentifikasi isu teoretis yang dikaji atau diteliti & \\
\hline 3 & Pendahuluan 1 & Pendahuluan: Masalah penelitian dinyatakan dengan jelas (problem statement) & \\
\hline 4 & Pendahuluan 2 & $\begin{array}{l}\text { Pendahuluan: Tujuan penelitian dinyatakan dengan jelas (teoretik dan } \\
\text { terapan/praktis) }\end{array}$ & \\
\hline 5 & Pendahuluan 3 & $\begin{array}{l}\text { Kajian atas penelitian relevan: Hubungan dengan penelitian terdahulu (kebaruan } \\
\text { dan manfaat) }\end{array}$ & \\
\hline 6 & Metode 1 & $\begin{array}{l}\text { Desain (atau paradigma) penelitian (kuantitatif, kualitatif, mixed methods, atau } \\
\text { kajian literatur) }\end{array}$ & \\
\hline 7 & Metode 2 & $\begin{array}{l}\text { Partisipan penelitian (cara pengambilan sampel, kriteria partisipan, populasi, } \\
\text { sampel) }\end{array}$ & \\
\hline 8 & Metode 3 & Metode pengumpulan data (wawancara, observasi, alat ukur) & \\
\hline 9 & Hasil 1 & Pencantuman effect size (koefisien korelasi, regresi) untuk penelitian kuantitatif & \\
\hline 10 & Hasil 2 & $\begin{array}{l}\text { Hasil: Laporkan analisis demografik atau uraian deskriptif yang relevan dengan } \\
\text { tujuan penelitian }\end{array}$ & \\
\hline 11 & Diskusi 1 & $\begin{array}{l}\text { Diskusi: Pernyataan mendukung atau tidak mendukung terhadap hipotesis } \\
\text { penelitian }\end{array}$ & \\
\hline 12 & Diskusi 2 & $\begin{array}{l}\text { Diskusi: persamaan dan perbedaan antara hasil penelitian saat ini dengan } \\
\text { penelitian terdahulu }\end{array}$ & \\
\hline 13 & Diskusi 2 & $\begin{array}{l}\text { Simpulan penelitian (dampak/validitas eksternal; menjawab pertanyaan } \\
\text { penelitian) }\end{array}$ & \\
\hline 14 & Pustaka Acuan 1 & Pustaka Acuan: sebagian besar merujuk pada artikel-artikel jurnal & \\
\hline 15 & Pustaka Acuan 2 & Lebih dari $80 \%$ referensi adalah terbitan 10 tahun terakhir & \\
\hline
\end{tabular}

Catatan. TIM RaDaR memuat 15 poin rekomendasi atau pedoman standar isi suatu artikel publikasi ilmiah. Acuan ini pula yang menjadi acuan isi dari tulisan editorial. Pedoman ini dapat digunakan untuk kebaikan bersama dengan mengikuti lisensi diseminasi ilmu pengetahuan $(C C-B Y)$.

Conversely, an interesting "Title" could be cited on a massive scale, without its content being critically read - if even read at all. Citations on a massive scale even occur on articles that never existed in the first place, often known as ghost or phantom references. One example of a phantom reference is an article titled "The Art of Writing a Scientific Article", which until July 2021 has been cited over 1,000 times or $250 \%$ more since it was first reported to be misscited by 400 other articles in September 2017 (Harzing \& Kroonenberg, 2017).

Aside from content, the choice of "Title" may cause reference sources to be over or under-cited (Jacso, 2006). van Raan (2004) coined the term "Sleeping Beauties in Science" for articles ignored or not cited (i.e., considered "sleeping") for prolonged periods, typically five to ten years, but subsequently garner enough interest and become frequently cited. Although to a lesser extent, this phenomenon also occurs in the field of psychology (Lange, 2005). It is unfortunate if this phenomenon occurs merely
Sebaliknya, "Judul" yang menarik boleh jadi akan disitat secara masif, tanpa pernah dibaca secara kritis atau bahkan tanpa pernah dibaca sama sekali. Pengutipan secara masif dapat terjadi bahkan untuk artikel-artikel yang sebenarnya tidak pernah ada atau dikenal dengan referensi atau kutipan hantu (phantom reference). Salah satu contoh referensi hantu adalah artikel berjudul "The Art of Writing a Scientific Article", yang hingga Juli 2021 telah dikutip lebih dari 1000 kali atau melonjak $250 \%$ sejak dilaporkan pertama kali, telah dikutip secara keliru oleh 400 artikel lain pada September 2017 (Harzing \& Kroonenberg, 2017).

Selain isi artikel, pemilihan "Judul" dapat mengakibatkan suatu referensi dikutip secara berlebihan atau berkekurangan (Jacso, 2006). van Raan (2004) mencetuskan istilah "Putri Tidur dalam Ilmu Pengetahuan" untuk menyebut artikel-artikel yang terabaikan dan tidak dikutip (dianggap "tertidur") untuk waktu yang lama, biasanya 5-10 tahun, namun kemudian menarik banyak perhatian dan dikutip berulang-ulang. Walaupun tidak banyak, namun hal ini juga terjadi di bidang psikologi (Lange, 2005). 
due to bad choices of "Title" (Ke et al., 2015). On the other hand, bad practices of choosing immensely interesting and even sensational "Titles" that do not reflect the article contents may be seen as deceptive or even as a treachery to science (Beleslin et al., 2017). Therefore, the information presented in this section of the article should be considered wisely and carefully, to avoid misuse for personal and temporary gains.

Not all readers actually read what they cite. Simkin and Roychowdhury (2002) even predicted that only $20 \%$ of authors, or more exactly 22 to $23 \%$ of them (Ball, 2002), actually read the papers that they cite. This practise has been occurring in such a massive scale that Simkin and Roychowdhury (2006) even suggested that a scholar's consent on the question "Have you read all the papers that you cite?" as an indicator for a form of deceit.

This can also be indicated by the error in drawing conclusions merely based on the "Titles" of the articles cited. Leng (2020) presented a phenomenal example in the form of article by Stang (2010) titled "Critical Evaluation of the Newcastle-Ottawa Scale for the Assessment of the Quality of Nonrandomized Studies in Meta-Analyses". This article is often cited as a supporting reference on the efficiency of Newcastle-Ottawa Scale (NOS), even though the article concluded its obscurity and cautioned against using the Newcastle-Ottawa Scale (NOS). Stang et al. (2018) reported that the article has been cited roughly 1,250 times. Problematically, according to Stang et al. (2018), randomized review on 100 articles citing the 2010 study (based on data from Web of Science) found that authors have used that article to support the use of Newcastle-Ottawa Scale (NOS) in systematic reviews, even though the opposite is true.

Larsson (1995) and Steel (1996) cautioned against the existence of bad and dangerous practices of citing references without critically reading them. Simkin and Roychowdhury $(2002 ; 2006)$ even suggested that $80 \%$ of writers do not read the references that they cite. This suggestion is due to the high level of
Adalah hal yang sangat disayangkan jikalau hal tersebut hanya dikarenakan kesalahan pemilihan "Judul" (Ke et al., 2015). Di sisi lain, praktik buruk pembuatan "Judul" yang sedemikian menarik bahkan sensasional namun tidak sesuai dengan isi artikel dapat dianggap sebagai penipuan bahkan pengkhianatan terhadap pengetahuan (Beleslin et al., 2017). Oleh karena itu, informasi yang disampaikan pada bagian ini dimohon dengan sangat digunakan secara cermat dan berhati-hati dan tidak disalahgunakan demi keuntungan pribadi dan sesaat.

Tidak semua penulis benar-benar membaca apa yang mereka kutip. Simkin dan Roychowdhury (2002) bahkan memperkirakan hanya sekitar 20\% penulis, atau lebih tepatnya antara $22-23 \%$ penulis (Ball, 2002), benar-benar membaca naskah yang mereka kutip. Praktik ini sedemikian masifnya, sehingga Simkin dan Roychowdhury (2006) bahkan mengusulkan bahwa persetujuan seorang ilmuwan terhadap pertanyaan "Apakah Anda membaca semua naskah yang Anda kutip?" merupakan indikator suatu bentuk kebohongan.

Hal ini dapat pula dikenali dari adanya kekeliruan penarikan simpulan hanya berdasarkan "Judul" artikel. Leng (2020) menyajikan salah satu contoh fenomenal berupa artikel Stang (2010) berjudul "Critical Evaluation of the Newcastle-Ottawa Scale for the Assessment of the Quality of Nonrandomized Studies in Meta-Analyses". Artikel ini seringkali dikutip sebagai referensi pendukung terhadap ketepatgunaan Newcastle-Ottawa Scale (NOS), padahal artikel tersebut menyimpulkan ketidakjelasan dan menyarankan kehati-hatian dalam penggunaan Newcastle-Ottawa Scale (NOS). Stang et al. (2018) melaporkan bahwa artikel tersebut telah dikutip sekitar 1250 kali. Masalahnya, menurut Stang et al. (2018), telaah acak terhadap 100 artikel berupa kajian literatur yang mengutipnya (berdasarkan data $\mathrm{Web}$ of Science) menemukan bahwa para penulis menggunakan artikel itu sebagai pendukung penggunaan Newcastle-Ottawa Scale (NOS) dalam tinjauan sistematis, walaupun pada kenyataannya justru sebaliknya.

Larsson (1995) dan Steel (1996) telah menyampaikan keberadaan praktik buruk dan berbahaya berupa mengutip referensi tanpa melakukan pembacaan secara kritis. Simkin dan Roychowdhury (2002; 2006) bahkan meyakini bahwa sekitar $80 \%$ penulis tidak membaca referensi yang mereka kutip. Hal ini 
misprint that most likely occur due to copying and quoting a number of references in a random fashion, without actually reading the works cited.

Since the dawn of the Internet era and the prevalence of electronic journal publications, readers of scientific articles have started to rely heavily on using a number of keywords to search for articles. The search is mostly centred on the "Title" and abstract sections of the articles. Keyword search is typically not widely used for full-text search. The main reasoning is the large number of search results, which could make it difficult for readers to pick and choose which articles to be further read and studied (Cooper, 2020). Upon understanding the importance of a "Title" in the search process for scientific articles, it is important to understand the main components of a title to be more easily searched, read, and hopefully cited.

Although largely similar, there are slight differences between "Titles" of quantitative articles (Cooper, 2020) and qualitative ones (Levitt, 2020). For quantitative articles, Cooper (2020) emphasized the importance of presenting the research variables, theoretical issues to be researched, and the population as the research focus. For qualitative articles, on the other and, the term 'variable' is often changed or equated with the term 'research focus' or 'research phenomenon'. Levitt (2020) supported the importance of presenting the main issue and topic of research, which is further detailed into a phenomenon to be studied, the type of participants, the data used, the context of the problem, and the research questions.

\section{I for Introduction}

The culture of writing "Introduction" is very much influenced by the writing style or formulation of a final project paper (thesis or dissertation). Often, editors or reviewers would encounter manuscripts that begin with very broad opening sections. For instance, "Indonesia is an archipelago that consist of diverse cultural backgrounds." Another example that we often encounter is when authors attempt to explain a phenomenon by using formalized descriptions from well-known institutions or organization, e.g., "According to the World Health organizations, adolescents are individuals aged 15 and above." diusulkan berdasarkan adanya tingginya tingkat kesalahan cetak (misprint) yang terjadi kemungkinan besar terjadi karena perilaku penyalinan kutipan dari sejumlah referensi secara acak (random) tanpa benar-benar membaca kutipan tersebut.

Sejak era Internet dan maraknya penerbitan jurnal elektronik, para pembaca artikel ilmiah mulai menggantungkan diri pada penggunaan sejumlah kata kunci untuk melakukan pencarian artikel. Pencarian biasanya dipusatkan pada bagian "Judul" dan abstrak. Pencarian kata kunci biasanya tidak banyak dilakukan pada isi naskah secara keseluruhan (full-text search). Alasan utama adalah banyaknya hasil pencarian yang akan diperoleh sehingga membuat pembaca kesulitan untuk memilah dan memilih naskah untuk dibaca dan dipelajari lebih lanjut (Cooper, 2020). Setelah memahami betapa penting peran "Judul" dalam penelusuran artikel ilmiah, penting untuk memahami komponen-komponen utama pada sebuah judul agar lebih mudah dicari, dibaca dan semoga dikutip.

Walaupun serupa, ada rincian yang sedikit berbeda antara "Judul" artikel kuantitatif (Cooper, 2020) dan kualitatif (Levitt, 2020). Untuk artikel kuantitatif, Cooper (2020) menekankan pentingnya penyajian variabel penelitian, isu teoretis yang sedang diteliti, dan populasi yang dijadikan fokus penelitian. Untuk artikel kualitatif, istilah variabel sering diganti atau disetarakan dengan istilah fokus atau fenomena penelitian. Levitt (2020) mendukung pentingnya penyajian isu utama dan topik yang menjadi fokus penelitian, yang dirincikan menjadi fenomena yang sedang diteliti, tipe partisipan, data yang digunakan, konteks masalah dan masalah atau pertanyaan yang ingin diteliti.

\section{Isi Sebuah Pendahuluan}

Budaya menulis "Pendahuluan" sangat dipengaruhi oleh cara penulisan atau penyusunan dokumen tugas akhir (skripsi, tesis, or disertasi). Seringkali penyunting atau mitra bestari menjumpai manuskrip yang diawali dengan kata pengantar yang terlalu umum atau luas. Contohnya, "Indonesia adalah negara kepulauan yang terdiri atas berbagai ragam latar belakang budaya." Contoh lain yang kerap kami temui adalah ketika penulis mencoba menjelaskan suatu fenomena dengan cara menggunakan deskripsi formal dari lembaga, institusi, atau organisasi terkemuka, seperti dalam kalimat "Remaja menurut lembaga kesehatan 
Another difficulty is the emergence of full manuscripts full of repeating sections of final research papers, e.g., "2.1. Definition of Independent Variables" or "2.1.1. Aspects of Dependent Variables." This condition is presumed to happen because the authors are used to the scientific writing patterns that consist of Chapters I to IV, or because the authors simply readapt their final research paper into a journal article. This culture is so strong and deeply ingrained, making it difficult for editors and authors to produce easily managed articles in the first place.

To find the ideal formula of an "Introduction," fellow researchers may read many different references. A large number of books and electronic guidelines have been published to help authors write articles more effectively (Belcher, 2019; Lester \& Lester Jr., 2015; Taylor \& Francis, 2020). Authors are also recommended to read the standards for writing research reports from the American Psychological Association (APA; Appelbaum et al., 2018; Levitt et al., 2018). Additionally, Table 1 in this article may serve as a master table on the criteria for the minimum content standards of an "Introduction." Various references and authorities have established guidelines on how to compose an "Introduction", and consequently we would like to take a different approach in this article. Instead of repeating the procedures to compose an "Introduction", this article aims to relate several findings or experiences commonly experienced in editing manuscripts. Then we aim to provide recommendations on the situations presented.

Table 1 indicated that problem statement, purpose of study, and connection to previous research are the three main parts to be included in an "Introduction." Editors often encounter that articles rewritten from final research papers still present the problem statements in the form of questions, e.g., "1.3. - Problem statement - What is the correlation between low emotional regulation strategy with depression level on employees of Company X?'. A problem statement signifies that authors state actual underlying issues that evoke a research activity, succinctly and concisely (Ellis \& Levy, 2008). Good examples of problem statements, for instance, "The level of depression has increased in the last decade," or "Equal access to education have not reached Indonesians who live outside of the urban areas." The problem statement would then be followed by clear evidence, dunia adalah individu yang telah berusia 15 tahun ke atas." Kendala lain yang ditemui adalah munculnya manuskrip yang penuh berisi pengulangan dokumen tugas akhir, seperti "2.1. Definisi Variabel Bebas" atau "2.1.1. Aspek-Aspek Variabel Tergantung." Kondisi ini kami duga muncul karena penulis telah terbiasa dengan pola kerja karya ilmiah yang tersusun atas Bab I hingga Bab $\mathrm{V}$ atau penulis menyadur ulang dokumen tugas akhirnya menjadi suatu artikel jurnal. Budaya ini begitu kuat dan mengakar sehingga menyulitkan penyunting dan para penulis untuk menghasilkan suatu artikel yang siap kelola sejak awal.

Untuk mengetahui rumusan ideal suatu "Pendahuluan," rekan peneliti dapat membaca banyak sumber. Buku maupun panduan elektronik telah banyak diterbitkan untuk membantu penulis menulis artikel jurnal (Belcher, 2019; Lester \& Lester Jr., 2015; Taylor \& Francis, 2020). Penulis juga sangat disarankan untuk membaca standar pelaporan penelitian menurut American Psychological Association (APA; Appelbaum et al., 2018; Levitt et al., 2018). Selain itu, pada tulisan ini, Tabel 1 menjadi rujukan utama (master table) kriteria minimum isi dari suatu "Pendahuluan." Banyak sumber dan otoritas telah menuangkan pedoman cara menyusun suatu "Pendahuluan" sehingga kami hendak mengambil sudut pandang yang berbeda pada tulisan ini. Alih-alih mengulang cara menyusun suatu "Pendahuluan," tulisan ini hendak memaparkan temuan atau pengalaman yang umum ditemui saat menyunting suatu manuskrip. Kami kemudian akan memberikan rekomendasi atau usulan untuk situasi yang kami paparkan tersebut.

Tabel 1 menunjukkan bahwa rumusan masalah (problem statement), tujuan penelitian, dan hubungan dengan penelitian terdahulu adalah tiga hal utama yang harus terpenuhi pada bagian "Pendahuluan." Penyunting kerap menjumpai artikel hasil dari rombakan tugas akhir menerjemahkan rumusan masalah dalam bentuk pertanyaan penelitian seperti: "1.3. Rumusan Masalah - Apakah ada hubungan antara rendahnya strategi regulasi emosi dengan tingkat depresi pada karyawan P.T. X?" Rumusan masalah berarti penulis menyatakan dengan singkat dan lugas permasalahan aktual yang mendorong suatu aktivitas penelitian (Ellis \& Levy, 2008). Salah satu contoh pernyataan rumusan masalah, misalnya, "Tingkat depresi mengalami peningkatan selama satu dekade terakhir" atau "Pemerataan akses ke pendidikan belum menyentuh warga Indonesia yang tinggal di 
in the form citations from supporting sources (Ellis \& Levy, 2008). This signifies that authors should differentiate between problem statement and the research question. Authors should also formulate problem statements supported by scientific proof, feasible to research, and pose a potential impact if said problem is left unanswered (Ellis \& Levy, 2008).

The next component of an "Introduction" is the purpose of the study. The purpose of a study is not the same as its research objectives. We often encounter authors stating the purpose of their studies by simply restating the title of the study, research objectives, or research questions. Several examples that we often encounter include: "The aim of this study is to test the relationship between workload stress and workplace fatigue", "This research aims to discover whether mindfulness meditation could reduce physiological stress response", or "We aim to test the constituent factors of Test Anxiety scale." The purpose of a study should instead be a general statement that indicates the direction and focus of a research (University of Washington, n.d.). Active words like understand, manage, discover, or develop could aid authors in formulating the purpose of their studies. Several examples on writing the purpose of a study include: "This study aims to develop a theoretical model of stress and fatigue in the workplace," "The aim of this study is to understand the effectivity of Dialectical Behavioral Therapy in reducing the symptoms of depression," or "We aim to discover primary source evidence on the validity of Adolescent Psychological Well-Being scale."

Lastly, "Introduction" should also indicate a connection with previous studies. Authors often spend a lot of time defining their research variables when composing the literature study in the "Introduction" section. Table 1 clearly indicates that the definition of research variables are not the minimum criteria of an "Introduction". Understanding the audience or readers of a journal article is an important component in writing the literature study of an "Introduction" (Armağan, 2013; Taylor \& Francis, 2020). Readers of academic articles are fellow scholars, researchers, colleagues, or experts who are fully versed in the phenomena or variables analyzed by the authors. As such, fellow researchers of psychological well- wilayah luar perkotaan.” Pernyataan ini kemudian diikuti dengan bukti berupa kutipan dari sumber yang mendukung rumusan masalah tersebut (Ellis \& Levy, 2008). Hal ini berarti penulis perlu membedakan rumusan masalah dengan pertanyaan penelitian. Penulis juga perlu menyusun suatu rumusan masalah yang didukung dengan bukti ilmiah, layak diteliti, serta membawa dampak apabila permasalahan tersebut tidak tertangani (Ellis \& Levy, 2008).

Komponen selanjutnya pada "Pendahuluan" adalah tujuan penelitian. Tujuan penelitian (purpose of the study) tidak sama dengan sasaran penelitian (research objectives). Seringkali, kami menemui penulis menuliskan tujuan penelitian dengan mengulang kembali judul penelitian, sasaran penelitian, atau pertanyaan penelitian. Contoh yang sering kami temui adalah: "Tujuan penelitian ini adalah menguji hubungan antara stres beban kerja dan kelelahan di tempat kerja", "Penelitian ini bertujuan untuk mengetahui apakah meditasi mindfulness dapat menurunkan respon stres fisiologik", atau "Kami bertujuan untuk menguji faktor-faktor penyusun alat ukur Kecemasan Menghadapi Ujian." Tujuan penelitian hendaknya merupakan pernyataan umum yang menunjukkan arah dan fokus penelitian (University of Washington, n.d.). Kata kerja aktif seperti memahami, mengelola, menemukan, atau mengembangkan dapat membantu penulis merumuskan tujuan penelitian. Beberapa contoh bentuk tujuan penelitian adalah: "Penelitian ini hendak mengembangkan model teoretik stres dan kelelahan di tempat kerja", "Tujuan penelitian ini adalah memahami efektivitas Dialectical Behavioral Therapy dalam menurunkan gejala depresi", atau "Kami bertujuan untuk menemukan sumber bukti kesahihan bagi alat ukur Kesejahteraan Psikologik Remaja."

Terakhir, "Pendahuluan" juga hendaknya menunjukkan hubungan dengan penelitian terdahulu. Penulis seringkali menghabiskan waktu dengan menjelaskan definisi dari variabel penelitian mereka pada saat menyusun kajian literatur di bagian "Pendahuluan." Tabel 1 menunjukkan dengan jelas bahwa definisi variabel penelitian bukanlah kriteria minimal suatu "Pendahuluan." Memahami audiens atau pembaca dari suatu artikel jurnal merupakan komponen penting menulis kajian literatur "Pendahuluan" (Armağan, 2013; Taylor \& Francis, 2020). Pembaca artikel jurnal adalah sesama ilmuwan, sesama peneliti, kolega, ataupun pakar yang telah memahami betul fenomena maupun variabel yang penulis kaji dalam artikel 
being or lecturers of developmental psychology no longer require the textbook definition of psychological well-being or the age ranges of adolescence. Readers of journal articles seek to understand what have been done in previous studies and how the current research aims to provide usefulness and merit. Authors are considered successful in presenting the state of the art (American Society of Civil Engineers, 2019) when readers could gain a new perspective from the study of literature in the "Introduction" section.

One useful suggestion in the writing of "Introduction" is to compose this section as a narrative. "Introduction" as a narrative means that authors should develop a persuasive story so that readers are interested to learn more about the research activities conducted that led to the manuscript at hand (Lingard $\&$ Watling, 2016). This suggestion helps readers free themselves from the mental burden that research reports should be written in a formal and rigid fashion. Conversely, writers should instead be allowed to write about empirical narratives, free from scientific jargons that may overcomplicate the manuscripts (Guillemard, 2017). "Introduction" as a narrative does not mean that authors simply create a non-fiction composition, but rather write using established scientific guidelines to write the "Introduction".

The next suggestion relates to the structure and types of paragraphs in the "Introduction." The paragraph structure typically consists of a main sentence supporting sentences - and a concluding sentence (Gray, 2019). There are several types of paragraphs and typically the "Introduction" section needs descriptive, comparative (compare-and-contrast), and narrative paragraphs (Gray, 2019). The formulation of paragraph structures often hinders the writing process in developing a narrative for the "Introduction" section that flows neatly. In several types of paragraphs, the concluding statement may be omitted as long as the logical flow of the paragraph is clear and coherent (Gray, 2019). Therefore, authors should focus on describing the research problems and composing the narrative of previously conducted studies. Authors may then compare and show the differences between the previous studies and the current research. Lastly, authors describe the purpose of the study, which embodies the research questions (and/or research hypotheses). This suggestion supports the jurnal tersebut. Oleh karena itu, sesama peneliti kesejahteraan psikologis atau dosen psikologi perkembangan anak tidak membutuhkan definisi kesejahteraan psikologis maupun batasan usia remaja. Pembaca artikel jurnal butuh untuk mengetahui hal apa saja yang sudah dilakukan pada penelitian terdahulu dan bagaimana penelitian yang terkini hendak memberikan nilai kebermanfaatan. Penulis berhasil menyajikan state of the art (American Society of Civil Engineers, 2019) saat pembaca memperoleh perspektif baru dari kajian literatur suatu "Pendahuluan."

Salah satu anjuran yang sangat berguna dalam penulisan "Pendahuluan" adalah bagian ini hendaknya disusun sebagai sebuah cerita. Pendahuluan sebagai sebuah cerita berarti penulis perlu membuat suatu kisah yang persuasif sehingga pembaca tertarik untuk mengetahui aktivitas penelitian yang dilakukan pada manuskrip tersebut (Lingard \& Watling, 2016). Anjuran ini membantu penulis melepaskan diri dari beban mental bahwa laporan penelitian harus ditulis secara formal dan kaku. Sebaliknya, penulis justru diperbolehkan untuk menuliskan suatu cerita empirik yang bebas dari jargon ilmiah yang memperumit suatu manuskrip (Guillemard, 2017). "Pendahuluan" sebagai suatu cerita bukan berarti penulis asal berkreasi menulis suatu karangan non-fiksi, melainkan penulis tetap berpedoman pada kaidah keilmuan saat memaparkan "Pendahuluan" suatu penelitian.

Anjuran berikutnya adalah berkaitan dengan struktur dan tipe paragraf pada "Pendahuluan." Struktur paragraf umumnya terdiri atas kalimat utama - kalimat pendukung - dan kalimat penutup (Gray, 2019). Paragraf juga memiliki beberapa tipe dan umumnya bagian "Pendahuluan" membutuhkan paragraf dengan tipe deskripsi, komparasi (membandingkan atau membedakan), dan narasi (Gray, 2019). Rumusan struktur paragraf seringkali menghambat proses penulis mengembangkan cerita "Pendahuluan" yang mengalir dengan rapi. Pada beberapa tipe paragraf, kalimat penutup (concluding statement) dapat ditiadakan selama alur logika dalam paragraf tersebut telah runtut dan jelas (Gray, 2019). Oleh karena itu, penulis perlu fokus untuk menguraikan permasalahan penelitian dan menyusun narasi penelitian yang telah dilakukan sebelumnya. Penulis kemudian membandingkan dan menunjukkan perbedaan antara penelitian terdahulu dan penelitian terkini. Terakhir, penulis menuliskan deskripsi tujuan penelitian yang di dalamnya dapat memuat pertanyaan penelitian 
preceding paragraphs on writing "Introduction" as a narrative. A different strategy should actually be applied when the authors begin to write the "Method" section.

\section{M for Method}

(Research) "Method" plays an important role in determining the quality of research conducted. Cooper (2020) analogized the process of conducting research with preparing a dish using a recipe. Lack of information, inaccuracy of instructions, and lack of message clarity could result in unreproducible research. Editors and reviewers typically could easily spot the errors on the information presented in manuscripts, but may often overlook unreported information. This is one of the reasons behind the emergence of detailed reporting guidelines, for both the quantitative and qualitative "Methods" (Kazak, 2018).

Generally, the "Method" section consists of several sub-sections, i.e., design, participants, and methods of data collection (procedures and instruments). In several journals, authors may find these sub-sections in different sequences. Authors are welcomed to adjust to the house style of their targeted journals. In the sub-section of research design, authors may introduce the approaches used to answer the research questions. These approaches may take the form of quantitative, qualitative, or mixed methods. Authors may describe the relevance of the research method chosen. The connection between the methods chosen and the research problems should be clearly laid out. This also means that that appropriate methodology must be applied to reach the purpose of the study, which is to provide a solution to the research questions presented in the Introduction section.

In the sub-section of research participants, authors describe sampling criteria based on demographic data, including the criteria for inclusion and exclusion from sampling. Authors also write the number of samples and the general demographic characteristics of the samples, e.g., gender, age, and socioeconomic status. Subsequently, authors may also write about specific demographic characteristics unique to the research, e.g., work tenure, time of (dan/atau hipotesis penelitian). Anjuran ini mendukung paragraf sebelumnya yang memuat tentang bagian "Pendahuluan" sebagai sebuah cerita. Strategi yang berbeda justru perlu diterapkan saat penulis mulai menyusun bagian "Metode."

\section{Menulis Metode}

"Metode" (Penelitian) berperan penting dalam menentukan kualitas dari penelitian yang dilakukan. Cooper (2020) pernah mengibaratkan bahwa melakukan penelitian itu seumpama menyiapkan hidangan menggunakan sebuah resep. Kekuranglengkapan informasi, kekurangakuratan keterangan, dan ketidakjelasan pesan berpotensi menghasilkan penelitian yang tidak dapat direproduksi. Para penyunting dan mitra bestari umumnya cukup mudah mengenali kekeliruan pada informasi yang disajikan dalam naskah namun seringkali melewatkankan informasi yang tidak terlaporkan. Hal ini ini menjadi salah satu alasan utama kemunculan panduan pelaporan terperinci, baik untuk "Metode" kuantitatif maupun kualitatif (Kazak, 2018).

Pada umumnya, bagian "Metode" terdiri atas subbagian desain, partisipan, dan metode pengumpulan data (prosedur dan instrumen). Pada beberapa jurnal, penulis mendapati urutan sub-bagian yang berbeda. Penulis dipersilakan menyesuaikan dengan gaya selingkung dari jurnal yang dituju. Pada sub-bagian desain penelitian yang dilakukan, penulis dapat memperkenalkan pendekatan yang digunakan untuk menjawab pertanyaan penelitian. Pendekatan ini dapat berupa metode kuantitatif, kualitatif, atau campuran. Penulis dapat menguraikan relevansi pendekatan metode yang dipilih. Hubungan antara metode dengan masalah penelitian harus jelas. Hal ini juga berarti bahwa metodologi harus sesuai untuk mencapai tujuan penelitian, yaitu untuk menjadi solusi pertanyaan penelitian yang disajikan pada bagian Pendahuluan.

Pada sub-bagian partisipan, penulis mendeskripsikan kriteria sampel berdasarkan data demografis, termasuk syarat untuk memasukkan atau mengeluarkan anggota dari sampel. Penulis juga menuliskan besar sampel dan karakteristik demografi umum dari sampel, seperti jenis kelamin, usia, status ekonomi. Kemudian, bisa dituliskan mengenai karakteristik demografi spesifik yang menjadi kekhasan dari penelitian ini, seperti lama bekerja, waktu pertama 
first clinical diagnosis, reaction time, etc. For categorical variables, information in the form of numbers and percentages may be provided. If there are numerous categories of variables, authors may write three to five main categories. Scale variables, e.g., age, work tenure, reaction time, etc., may be specifically written in the form of minimum and maximum ranges of the participants, along with mean and standard deviation values in parentheses. For instance: "The age of the participants in this study ranges from 19 to 45 years old $(M=27.73, S D=5.78)$ ". Further, authors describe how research participants or respondents were acquired, such as the sampling techniques used. Authors may also report the response rate (the percentage of the number of participants who answered the research instrument compared to the number of sample determined at the beginning of the research), place, and time of research. In addition, information may be provided that the research conducted has received ethical clearance, that the ethical standards for research have been fulfilled, and that the study has a contingency plan if something would have happened in the duration of the research. Regarding this, we have provided a number of information that can be accessed online (Abraham, 2021; Siaputra et al., 2019).

In the sub-section of research instrument, upon writing the title of the research instrument used and how it was developed, authors describe the aims of the instruments used in data collection, how the instruments were used, and how they were assessed. The instruments may take the form of survey, questionnaire, list of interview questions, list of behaviors to be observes, etc. If the instruments used are licensed psychological tests, authors should include proof of license to use the test for research. Further, for other tests provided by the developers freely on the web, journal, or personal communication; be sure to write the appropriate references on the web, journal, or other sources as requested by the developers. Provide constructive and measurable information, if there are dimension or sub-dimensions to be measured, the development of the tests (the version used in the data collection process), the number of questions or statements, scoring of the tests, and information from other studies or the authors regarding psychometric measurements conducted using the same instruments. Authors may report the reliability coefficients, such as inter-rater reliability, test-retest reliability (including time intervals of testing), or internal consistency for composite scales. Whenever mendapatkan suatu diagnosis klinis, waktu reaksi, dan lain sebagainya. Untuk variabel yang bertipe kategorikal, bisa diberikan keterangan mengenai jumlah dan persentase. Jika ketegori dari variabel cukup banyak, bisa dituliskan tiga sampai lima kategori terbesar. Khusus untuk variabel yang bertipe scale, seperti usia, lama bekerja, waktu reaksi, dan lain sebagainya bisa dituliskan jangkauan minimum dan maksimum dari partisipan beserta nilai rerata dan simpangan bakunya dalam tanda kurung. Contoh: "Usia partisipan dalam penelitian ini adalah 19-45 tahun $(M=27.73, S D=5.78)$ ". Penulis kemudian menuliskan cara mendapatkan partisipan atau responden penelitian, seperti teknik pengambilan sampel. Penulis juga dapat menuliskan response rate (persentase banyaknya partisipan yang menjawab instrumen penelitian terhadap besar sampel yang ditetapkan pada awal penelitian), tempat, waktu pelaksanaan dari penelitian. Selain itu, keterangan mengenai penelitian yang dilakukan ini sudah melalui persetujuan dari komite etik, standar etika penelitian terpenuhi, dan adanya rencana penanggulangan jika terjadi sesuatu ketika pelaksanaan penelitian. Mengenai hal ini, kami telah menyediakan sejumlah sumber daya informasi yang dapat diakses secara daring (Abraham, 2021; Siaputra et al., 2019).

Pada sub-bagian instrumen penelitian yang digunakan, setelah menuliskan judul instrumen penelitian beserta pembuatnya, penulis mendeskripsikan tujuan instrumen yang digunakan dalam mengumpulkan data, menjelaskan cara penggunaan instrumen, dan cara menilai. Instrumen ini dapat berupa survei, kuesioner, daftar pertanyaan untuk wawancara, daftar perilaku yang diobservasi, dan lain sebagainya. Jika instrumen yang digunakan adalah alat tes psikologis yang berlisensi, harap sertakan perizinan penggunaan alat tes tersebut untuk melakukan penelitian. Kemudian, untuk alat tes lain yang diberikan oleh pembuat alat tes secara bebas pada web, jurnal, atau komunikasi pribadi; pastikan untuk menuliskan rujukan web atau jurnal atau hal-hal yang diminta oleh pembuat alat tes tersebut. Berikan informasi konstruk yang diukur, jika ada dimensi atau bahkan sub-dimensi yang diukur, perkembangan alat tes ini (versi yang akhirnya digunakan dalam pengambilan data penelitian), jumlah butir pertanyaan atau pernyataan, cara perolehan skor dari alat tes, dan keterangan dari penelitian-penelitian lain atau penulis sendiri, mengenai hasil uji psikometri yang pernah dilakukan pada alat ini. Penulis dapat melaporkan koefisien reliabilitas, seperti inter-rater reliability, test-retest reli- 
possible, authors should also report the general demographic data from the psychometric test samples. Furthermore, if deemed relevant, authors should also write the convergence and determinant coefficients for information on the validity of the tests used.

In the sub-section of research procedure or process, authors need to inform the readers on the activities conducted before, during, and after the research. For instance, prior to conducting the research the authors requested a review from the ethical committee, acquired permits to conduct research, presented their proposal to the ethical committee in which the data collection took place (for instance, when conducting research in hospitals), design of the web or mobile-based questionnaire, etc. If during the research, for example, there are injured participants or if their responses on the instruments imply a cause for concern, what did the research team do to address these issues. This relates to contingency planning applied by the field research teams. Further, upon completion of data collection and upon the conclusion of the study, report whether the contingency plan applied in the field when the study took place was sustained - if so, for how long? These concerns may provide guidelines for younger researchers to learn from their predecessors. Additionally, a clear research procedure enables future replication of the research by subsequent researchers.

In several cases, additional explanations are often needed in the form of data analysis technique. In this sub-section, authors elaborate on the data analysis techniques (e.g., statistical techniques) applied in answering the research questions. Authors should write the notable differences between the acquired and analyzed samples. Authors explain the reasoning behind not using some of the gathered data in the data analysis, e.g., because characteristics of the participants are not in line with the sampling characteristics of the research, that some participants did not complete the questionnaires given, etc. If there are incomplete data, the criteria that made certain data points incomplete, followed with the methods used to replace the incomplete data, should be explained (if replacement was conducted). Then, the authors also define and explain the methods used to handle outliers. Further, the authors analyze ability (termasuk interval waktu dari pengambilan tes), atau internal consistency untuk skala komposit. Jika memungkinkan, laporkan juga data demografi umum dari sampel uji psikometrik itu dilakukan. Kemudian, jika relevan, penulis juga menuliskan koefisien konvergen dan diskriminan untuk keterangan validasi dari alat tes yang digunakan.

Pada sub bagian prosedur atau proses penelitian, penulis perlu menginfokan kepada pembaca mengenai aktivitas-aktivitas yang dilakukan sebelum, selama, dan sesudah penelitian. Sebagai contoh, pada masa sebelum melakukan penelitian, peneliti meminta ulasan dari komite etik, permohonan izin melakukan penelitian, presentasi di hadapan komite etik di tempat pengambilan data (ketika mengambil data di rumah sakit, misalnya), mendesain tampilan kuesioner di web atau aplikasi telepon pintar, dan lain sebagainya. Saat melakukan penelitian, misalkan jika ada partisipan yang cedera atau dari respon dia terhadap alat ukur menyiratkan ada sesuatu yang harus diperhatikan, hal-hal apa yang dilakukan oleh tim peneliti. Hal ini berkaitan dengan rencana penanggulangan yang diaplikasikan tim peneliti di lapangan. Kemudian, setelah peneliti selesai mengambil data dan penelitian berakhir, apakah penanggulangan yang dilakukan di saat berlangsungnya penelitian ini berlanjut - jika ya, sampai berapa lama. Hal-hal tersebut dapat menjadi masukan dan petunjuk bagi para peneliti muda untuk dapat belajar dari peneliti pendahulunya. Selain itu, prosedur penelitian yang jelas memungkinkan penelitian yang dilakukan dapat direplikasi oleh peneliti berikutnya.

Pada beberapa kasus, terkadang diperlukan tambahan penjelasan berupa teknik analisis data. Pada sub bagian ini, penulis menguraikan teknik analisis data (misalnya teknik statistik) yang diterapkan dalam menjawab pertanyaan penelitian. Hendaknya penulisan di bagian ini menuliskan mengenai perbedaan besar sampel yang diperoleh dengan yang dianalisis. Penulis menjelaskan alasan dari data yang diperoleh tidak digunakan dalam analisis data, misalnya karakteristik partisipan yang tidak sesuai dengan karakteristik sampel dari penelitian, partisipan tidak mengisi lengkap kuesioner yang diberikan, dan lain sebagainya. Jika ada data yang tidak lengkap, maka kriteria apa yang membuat suatu data disebut tidak lengkap kemudian metode apa yang digunakan untuk menggantikan data yang tidak lengkap (jika dilakukan penggantian). Kemudian penulis juga membuat definisi dan metode 
the distribution of the research data and data transformation (if conducted). Subsequently, authors write the inferential statistics techniques used, according to the sequence of the techniques applied in answering the research questions. When using certain methods of analysis techniques that are perhaps unfamiliar to the readers, authors should ensure that adequate background information is provided regarding the choice of methods used.

Authors are expected to write the description in the "Method" section thoroughly and transparently. This is done for the sake of replicability of the research, whether by the authors themselves or by other researchers. Consequently, the issue of replicability (repetition of method) and reproducibility (repetition of results) can be better managed (Stevens, 2017).

\section{$R$ for Results}

In the "Results" section of the article, write the results relevant to the research question. Description may begin with illustration of the research variables, e.g., detailed demographic data (usually in the form of tables), percentages of participants in the categories (high-low) of research variables, etc. In qualitative research, authors may describe some background information of the respondents, including the similarities and differences among them.

In the "Results" section, describe the acquired meanings and understanding from the data analysis conducted. Describe the compatibility or incompatibility between the research findings and the purpose of the study and/or the study procedures. Use tables or figures effectively and efficiently, in just the right number, and between between-tables or between-figures information. Do not confuse the readers with too many tables without any explanation. The titles of the tables or figures should reflect their contents.

Particularly for results of statistical tests, write the coefficients/values attained using the statistical techniques entirely. Avoid only presenting the coefficients of significance. After writing the coefficients of significance, also present the extent of the effects, for instance Cohen's D on t-test or yang digunakan untuk menangani outliers pada data. Kemudian, penulis memberikan analisis mengenai distribusi data penelitian dan transformasi data (jika dilakukan). Setelah itu, peneliti menuliskan teknik statistik inferensial mengikuti urutan teknik analisis yang diterapkan pada data penelitian guna menjawab pertanyaan penelitian. Saat menggunakan metode dalam melakukan teknik analisis yang mungkin tidak familiar bagi pembaca, perlu dipastikan untuk memberikan informasi latar belakang pemilihan metode ini.

Uraian dalam bagian "Metode" diharapkan dapat ditulis dengan teliti dan transparan. Hal ini membuat penelitian yang dilakukan penulis dapat direplikasi di masa mendatang oleh peneliti sendiri atau peneliti lain. Dengan demikian, isu replikabilitas (keberulangan metode) dan reproduksibilitas (keberulangan hasil) dapat ditangani dengan lebih baik (Stevens, 2017).

\section{Risalah Hasil}

Pada bagian penulisan "Hasil", tuliskan hasil penelitian yang relevan dengan pertanyaan penelitian. Uraian bisa diawali dengan gambaran deskriptif dari variabel-variabel yang diteliti, misalnya data demografi yang detil (biasanya dalam bentuk tabel), persentase partisipan pada kategori-kategori (tinggirendah) pada variabel yang diteliti, dan lain sebagainya. Jika dalam penelitian kualitatif, dapat diuraikan mengenai latar belakang dari responden, termasuk persamaan dan perbedaan antar-responden.

Pada bagian "Hasil", deskripsikan arti dan pemahaman yang didapatkan peneliti dari analisis data yang dilakukan. Deskripsikan kesesuaian atau ketidaksesuaian antara temuan dengan tujuan penelitian dan prosedur penelitian. Gunakan tabel atau bagan gambar secara efektif dan efisien, jangan terlalu banyak dan berilah keterangan antar-tabel atau antargambar. Jangan tinggalkan pembaca bingung akan banyaknya suguhan tabel tanpa ada keterangan. Judul tabel atau gambar, hendaknya sesuai dengan isinya.

Khusus hasil uji statistik, tuliskan secara lengkap koefisien/nilai yang diperoleh dari teknik analisis yang dilakukan. Tidak hanya mencantumkan koefisien signifikansi. Setelah penulisan signifikansi, berikan juga besar efek, misalkan Cohen's $D$ pada uji t (t-test) atau koefisien determinasi $\left(r^{2}\right)$ untuk 
determination coefficient $\left(r^{2}\right)$ for correlation. Write the results entirely, e.g., for writing the correlation results: " $r(41)=.48 ; p<.05 ; r^{2}=.23$." This example states that: "This correlational research has a correlation coefficient of 48 , significant within $5 \%$ significance level, with determination coefficient of .23 , and this correlation was attained using 41 samples." The guidelines for writing out statistical tests can be seen in statistical textbooks or the American Psychological Association (APA) guidelines for scientific writing (Section 6.32-6.48 in American Psychological Association [APA], 2020).

Focus the "Results" section to discuss the researchers' findings. Authors guide the readers to understand the participant or respondent data and the analysis of findings from the research conducted. What is the connection between the descriptive data, quotes from interviews, observational findings, results of statistical tests, and so on? Authors should guide the readers to comprehend.

\section{D for Discussion}

"Discussion" is the section that truly reflects the authors' mastery on the substance of the research. If in the "Introduction" section, the authors compose various premises directed towards the formulation of the research hypotheses, in the "Discussion" section the authors conduct analysis and interpretation on the hypotheses tested.

The research results may or may not be in line with the hypotheses formulated. How the authors guide readers to accept this incoherence as something that still "makes sense" is a unique challenge for authors. What authors should do is provide a logical argument on the incompatibility by: (1) analyzing the similarities and differences between the research results with other studies; (2) presenting the authors' own observation that was missing from the "Introduction" section; or (3) conducting an introspective study on the methods used and the characteristics of the data gathered. By doing so, authors may contribute to novel knowledge through the "Discussion" section. korelasi. Tulislah secara lengkap, contoh untuk penulisan hasil korelasi: " $r(41)=.48 ; p<.05 ; r^{2}=.23$." Contoh tersebut menyatakan bahwa: "Penelitian korelasional ini memiliki koefisien korelasi .48 yang signifikan pada tingkat signifikansi 5\%, dengan koefisien determinasi .23, dan korelasi ini didapatkan dengan besar sampel 41." Penulisan uji statistik dapat dilihat pada buku teks statistik atau panduan American Psychological Association (APA) untuk penulisan ilmiah (Section 6.32-6.48 dalam American Psychological Association [APA], 2020).

Fokuskan bagian "Hasil" penelitian untuk membahas temuan penelitian penulis. Penulis menjadi pemandu bagi pembaca untuk memahami data partisipan atau responden dan temuan analisis yang didapatkan dari penelitian yang dilakukan penulis. Apakah ada koneksi antara data deskriptif, data kutipan wawancara, hasil observasi, hasil uji statistik, dan lain sebagainya? Penulis hendaknya memandu pembaca untuk memahaminya.

\section{Diskusi atau Pembahasan}

"Diskusi" ("Pembahasan") merupakan bagian yang sejatinya paling menunjukkan penguasaan penulis terhadap substansi penelitian. Bila dalam "Pendahuluan", penulis menyusun berbagai premis yang mengarah pada susunan hipotesis penelitiannya, maka dalam "Diskusi" ("Pembahasan"), penulis melakukan analisis dan interpretasi terhadap hasil pengujian hipotesis tersebut.

Dapat terjadi, hasil penelitian tidak sejalan dengan hipotesis penulis. Cara penulis membawa pembaca untuk menerima ketidakselarasan tersebut sebagai hal yang masih "masuk akal" ("makes sense") merupakan tantangan tersendiri bagi penulis. Hal yang perlu penulis lakukan adalah memberikan argumen logis atas kemasukakalan tersebut dengan cara: (1) menelaah persamaan dan perbedaan antara hasil penelitian saat ini dengan penelitian orang lain; (2) menyajikan hasil observasi penulis sendiri yang luput terdokumentasikan dalam "Pendahuluan"; atau (3) melakukan kajian introspektif terhadap metode yang telah dilaksanakannya dan karakteristik data yang telah terkumpul. Dengan demikian, penulis dapat mengkontribusikan pengetahuan baru melalui "Diskusi" ("Pembahasan"). 
In conducting any of the three strategies above, citation from varied sources of reference is essential. For a number of authors, particularly novice authors, we often encounter the use of a small number (one to three) references in pages upon pages of "Discussion". This is problematic because it implies that the research conducted by the authors is isolated from the vast network of existing body of scientific knowledge. Even though, an ancient proverb tells us that "There is nothing new under the Sun". This signifies that there are always other relevant studies, whether directly or indirectly related, to be used as points of reference or comparison by authors.

These comparisons function not only to examine similarities and differences, but also to deepen the theoretical interpretation on the research findings. Authors' wide theoretical worldview is paramount in this instance. In essence, the composition of "Discussion" is not merely a "technical writing" issue (a skill that may be acquired through various writing workshops), but rather a matter of knowledge accumulation on the topic at hand. The more theoretical knowledge and practical experience that one has on a topic, even before the commencement of the study, the better one's comprehension on the breadth and breadth of the topic - in short, the state of the art of the topic. Consequently, the "Discussion" section also reflects the cumulative experience that authors have on the research topic.

An important matter in the "Discussion" section (which are also essential in the "Introduction" and "Method" sections) is readability. The presence of scientific journals in public libraries, open electronic libraries, and general book stores (we have encountered, for example, Jurnal Prisma and Jurnal Perempuan in these stores) indicate that journal editors would like for practitioners and the general public, to a certain extent, to be able to experience and benefit from these scientific publications. In this context, the general public is typically apprehensive about the use of super-specialized jargons in the writings, such that the writings become difficult to understand, let alone to benefit from. The use of jargons in itself is not an issue, provided that the jargons: (1) are self-explanatory or part of a relatively general knowledge vocabularies in certain fields of
Dalam melakukan ketiga cara di atas, pengutipan terhadap sumber rujukan yang bervariasi sangat diperlukan. Pada sejumlah penulis, khususnya penulis pemula, ditemukan penggunaan hanya segelintir (satu sampai tiga) rujukan pada berhalaman-halaman "Diskusi" ("Pembahasan"). Hal ini problematis karena menyiratkan seolah-olah riset yang dilakukan oleh penulis merupakan riset yang terisolasi dari jejaring pengetahuan ilmiah yang ada. Padahal, sebuah pemeo memberitahukan kita bahwa "Tidak ada yang baru di bawah Matahari". Hal ini bermakna bahwa selalu ada penelitian lain yang relevan, baik yang terkait langsung maupun tak langsung, untuk dibandingkan dengan penelitian penulis.

Perbandingan tersebut berfungsi bukan hanya untuk melihat persamaan dan perbedaan saja, melainkan juga untuk memperdalam penafsiran teoretis terhadap temuan penelitian. Wawasan teoretis penulis sangat diharapkan dalam hal ini. Oleh karenanya, penyusunan "Diskusi" ("Pembahasan") sesungguhnya bukanlah "persoalan teknis penulisan" (yang dapat diperoleh melalui berbagai bengkel kerja [workshop] penulisan) semata, melainkan soal kumulasi pengetahuan tentang topik yang diteliti. Semakin banyak bacaan dan pengalaman praktis seseorang terhadap topik tersebut, bahkan jauh sebelum penelitian dilakukan, semakin orang tersebut memiliki pencerapan (comprehension) yang baik mengenai keluasan dan kedalaman topik tersebut, singkatnya state of the art dari topik. Dengan demikian, bagian "Diskusi" ("Pembahasan") pada satu sudut pandang mencerminkan "jam terbang" yang dimiliki penulis atas topik penelitian.

Sebuah hal yang penting dalam "Diskusi" ("Pembahasan") (sebenarnya juga dalam "Pendahuluan" dan "Metode") adalah keterbacaan. Ditaruhnya jurnaljurnal ilmiah di perpustakaan-perpustakaan umum, perpustakaan elektronik yang terbuka, bahkan di toko-toko buku umum (kami pernah menjumpai, misalnya Jurnal Prisma dan Jurnal Perempuan) menunjukkan bahwa pengelola jurnal menghendaki agar orang awam dan praktisi dalam taraf tertentu dapat ikut menikmati dan memanfaatkan jurnal ilmiah ini. Dalam konteks ini, yang sering diprihatinkan masyarakat adalah penggunaan jargon superspesialistik dalam tulisan, sehingga tulisan menjadi sulit dipahami, apalagi dimanfaatkan. Penggunaan jargon tentu bukan merupakan masalah, sepanjang jargon tersebut: (1) merupakan jargon yang terjelaskan dengan sendirinya (self-explanatory) atau per- 
science; or (2) have been defined, at least the surface meanings, in previous parts of the article, such that readers may understand the use of the jargons without a lot of doubt. The issues related to readability should be more closely discerned in psychometric articles or psychological testing. It is advised that authors should formulate more relatable sentences to accompany psychometric language in "Discussion".

The "Discussion" section should also be utilized by readers to emphasize to the advantages of the reported study. For instance, the sentence "This research used two research variables, different from the previous study that used more than two variables," would cause the readers to question: "Why they should read a study report that contribute less to scientific knowledge compared to similar studies that can easily be found in journal databases". This could also create a sense of discontent for readers who have spent a considerable amount of time reading from "Introduction" to "Discussion". The research advantages should be presented proportionally. For instance, it is improper for authors to state that they have successfully disputed the theory of Psychoanalysis, while their findings are limited to the Oedipus Complex phenomenon that did not apply to children in their region.

Unequivocally, in addition to the merits of research, authors should also state the research limitations in the "Discussion" section. In addition to showing academic modesty, writing about the limitations of research may also serve as information for the upcoming researchers to address these limitations. It is true that the development of scientific knowledge is a result of a communal effort with persistence and patience.

A pitfall to avoid in the writing of the limitation section is over-criticizing one's own research. For instance, because the authors find that their hypotheses were not supported by the research data, or often called "negative result", in the discussion of research limitations the authors state that the instrument used had low content validity, even though bendaharaan pengetahuan yang relatif umum dalam bidang ilmu tersebut; atau (2) sudah dijelaskan maknanya, minimal sepintas lalu, pada bagian-bagian sebelumnya dari naskah, sehingga dapat dipahami oleh pembaca tanpa perasaan bimbang. Masalah sehubungan dengan keterbacaan ini lebih perlu diperhatikan lagi dalam artikel-artikel psikometri atau pengukuran psikologis. Sebaiknya, dalam "Diskusi" ("Pembahasan"), penulis menyampaikan kalimat-kalimat yang lebih membumi dan seharihari untuk mendampingi bahasa psikometri.

Bagian "Diskusi" ("Pembahasan") hendaknya juga dimanfaatkan oleh penulis untuk memperlihatkan keunggulan dari studi yang tengah dilaporkannya. Sebagai contoh, kalimat "Penelitian ini menggunakan dua variabel penelitian, berbeda dari penelitian sebelumnya yang menggunakan lebih dari dua variabel", akan menimbulkan pertanyaan di kalangan pembaca: "Untuk apa saya membaca sebuah penelitian yang justru lebih sedikit sumbangsih pengetahuannya daripada penelitian sejenis yang dapat saya temukan dari pangkalan jurnal". Hal ini dapat menimbulkan kekecewaan pada pembaca yang telah menghabiskan waktunya untuk membaca mulai dari "Pendahuluan" sampai dengan "Diskusi" ("Pembahasan"). Keunggulan penelitian dalam hal ini hendaknya ditampilkan sesuai porsinya. Sebagai contoh: tidak tepat jika penulis menyatakan bahwa penulis telah berhasil membantah teori Psikoanalisis, sementara yang ditemukannya terbatas pada fenomena Oedipus Complex yang tidak berlaku pada anak-anak di wilayah kabupatennya.

Tentu saja, di samping keunggulan, penulis juga perlu menyampaikan keterbatasan penelitian di dalam "Diskusi" ("Pembahasan"). Dalam hal ini, di samping penulis mewujudkan kerendahhatian akademiknya (academic modesty), limitasi penelitian juga dapat menjadi informasi bagi peneliti berikutnya untuk menambali keterbatasan ini. Memang, dari hal ini tampak bahwa pengembangan pengetahuan ilmiah merupakan hasil gotong-royong yang tekun dan sabar.

Hal yang perlu diwaspadai dalam menulis bagian keterbatasan (limitasi) ini adalah sikap "terlampau kritis" (over-criticizing) terhadap penelitian sendiri. Sebagai contoh, oleh karena penulis menjumpai bahwa hipotesisnya tidak didukung oleh data penelitian, atau sering disebut sebagai "hasil negatif" (negative result), dalam diskusi tentang keterbatasan 
validity of the items were quite high. This would lead readers to question why research with such fundamental flaw was even considered to be published in a scientific journal in the first place. Why wouldn't the authors first review the content validity before the data collection process? This also implies that the authors rushed the research process, thus overlooking an important step in the process. In essence, each study needs not only passion, but also patience.

Another common issue found in the "Discussion" section is the lack of in-depth analysis on the main results of the research. For example, in a correlational research, some authors tend to discuss matters other than the correlation results, instead discussing additional analyses (e.g., categorization of high-mediumlow psychological variables among the research participants). Additionally, some authors discuss the demographic data (gender, age, religion, etc.) exclusively without tying them to the correlation results. Consequently, rather than being enriched, the "Discussion" instead becomes hazy with so many additional explanation or results. On several "Discussions", it is found that there are "contradictions" between the explanation of the main results with the explanation of the additional results. This requires authors to pay careful attention to the difference between the two types of results (i.e., main and additional results). The "Discussion" of the main analysis should be proportionally greater than additional analyses (e.g., $70 \%$ and $30 \%$ respectively).

The "Discussion" of research results should consider the characteristics of the statistical analyses conducted. For instance, findings from a correlational research stated that there is a positive correlation between resilience and psychological well-being. Often, authors would discuss the results of this correlation in one-way term, e.g., how resilience may predict psychological well-being. However, the authors neglect to discuss the opposite, i.e., whether and how psychological wellbeing may predict resilience. In this case, the authors should refer back to their Statistics courses, penelitian, penulis menyatakan bahwa alat ukurnya memiliki validitas isi yang rendah meskipun validitas butir-butirnya lumayan tinggi. Hal ini akan menimbulkan pertanyaan, mengapa sebuah penelitian yang memiliki kekurangan fundamental seperti itu diajukan untuk dimuat di jurnal ilmiah? Mengapa tidak terlebih dahulu validitas kontennya diperbaiki sebelum tahap pengambilan data? Hal ini juga menyiratkan bahwa penulis tergesa-gesa dalam melaksanakan proses penelitian, sehingga proses yang penting diluputkan. Padahal, setiap penelitian membutuhkan bukan hanya passion (semangat, gairah), melainkan juga patience (kesabaran).

Masalah berikutnya yang sering dijumpai dalam "Diskusi" ("Pembahasan") adalah penulis kurang memberikan bedahan yang mendalam terhadap hasil penelitian utama (main results). Sebagai contoh, pada sebuah penelitian korelasional, penulis malah lebih banyak mendiskusikan bukan hasil korelasinya, melainkan analisis tambahannya (misalnya penyandangan kategori tinggi-sedang-rendah dari variabelvariabel psikologis yang diteliti pada partisipan penelitian). Di samping itu, ada juga penulis yang mendiskusikan data-data demografis (jenis kelamin, usia, agama, dan sebagainya) secara eksklusif tanpa mengaitkannya dengan hasil korelasi. Dengan demikian, "Diskusi" ("Pembahasan") bukannya semakin kaya, melainkan menjadi semakin kabur, dengan banyaknya penjelasan atas hasil tambahan. Bahkan pada beberapa "Diskusi" ("Pembahasan") ditemukan bahwa penjelasan atas hasil utama "bertabrakan" dengan penjelasan atas hasil tambahan. Hal ini membutuhkan amatan yang utuh dan cermat dari penulis terhadap kedua jenis hasil penelitian ini (utama, tambahan). Hendaknya, porsi penulisan "Diskusi" ("Pembahasan") atas hasil analisis utama lebih banyak daripada Pembahasan atas hasil analisis tambahan (misalnya, 70\% berbanding 30\%).

"Diskusi" ("Pembahasan") hasil penelitian hendaknya memperhatikan dengan cermat sifat dari analisis statistik yang dilakukan. Sebagai contoh, sebuah temuan hasil penelitian korelasional menyatakan bahwa terdapat hubungan positif antara resiliensi dengan kesejahteraan psikologis. Seringkali, penulis mendiskusikan hasil korelasi ini secara satu arah, misalnya, bagaimana resiliensi dapat memprediksikan kesejahteraan psikologis. Namun penulis lupa untuk mendiskusikan arah sebaliknya, bagaimana kesejahteraan psikologis dapat memprediksikan resiliensi. Dalam hal ini, penulis perlu kembali pada pelajaran- 
which emphasize that there are no independent and dependent variables in a correlational research. More fundamentally, authors should always remember that the significance of "independence" in independent variables, and "dependence" in dependent variables.

For the "Discussion" to be accurate and weighty, authors should strengthen their understanding of basic characteristics of statistical analysis. the difference between "negative correlation" and "no correlation" notwithstanding. Many authors still explain no correlation as negative correlation. Similarly, explaining the results of a regression analysis with causal terminology (cause-and-effect, affect-be affected by) in the Discussion section, is unacceptable in the standard of good practices for "Discussion".

The characteristics of the research approach should also be considered. It is common for "Discussion" of quantitative research to use deductive approach. The sequence is: (1) state the research results; (2) discuss the theories used as a comparison; then (3) compare the analyzed data with the theories mentioned. However, for qualitative research, not to mention phenomenological research, such sequence is uncommon. In this type of research, the authors should "let the data speaks for itself" instead, then subsequently juxtapose the findings with established theories (inductive approach). Meaning, in accordance to the philosophy of qualitative research, authors should initially keep their assumptions. Yet what is often encountered in the "Discussion" section, authors already start with a number of assumptions that they present in the beginning of each paragraph as the frame with which to discuss their research data. This is contrary to the spirit and the intent of qualitative research.

Some "Discussion" of research results also tend to lead to overgeneralization. For example, a research was conducted on a small number of university students in the Jakarta metropolitan area, but it is discussed as if the research result is applicable to "all Indonesians," including those residing in rural areas. Another example is when research results show a certain degree of contradiction with a theory or previous research, but the authors claim pelajaran Statistika yang menekankan bahwa dalam sebuah penelitian korelasional, tidak ada variabel bebas, dan tidak ada variabel tergantung. Lebih mendasar lagi, penulis perlu senantiasa mengingat hakikat "kebebasan" dari variabel bebas, dan hakikat "ketergantungan" dari variabel tergantung.

Agar "Diskusi" ("Pembahasan") menjadi akurat dan bernas, pemahaman dasar tentang sifat dari hasil analisis statistik perlu diperkuat. Tidak terkecuali, perbedaan antara "korelasi negatif" dan "ketiadaan korelasi". Masih cukup banyak penulis yang menjelaskan ketiadaan korelasi seolah-olah sebagai korelasi negatif. Demikian pula, menjelaskan sebuah hasil analisis regresi dengan menggunakan terminologi kausal (sebab-akibat, mempengaruhi-dipengaruhi) dalam "Diskusi" ("Pembahasan"), merupakan hal yang tidak dapat diterima dalam sebuah standar Pembahasan yang baik.

Sifat dari pendekatan penelitian juga hendaknya memperoleh perhatian dari penulis. Lazimnya, "Diskusi" ("Pembahasan") sebuah hasil penelitian kuantitatif menggunakan pendekatan deduktif. Rangkaiannya adalah: (1) kemukakan hasil penelitiannya; (2) sampaikan teori yang akan digunakan sebagai pembanding; lalu (3) bandingkan data yang diperoleh dengan teori tersebut. Namun untuk penelitian kualitatif, lebih-lebih penelitian jenis fenomenologis, rangkaian tersebut merupakan ketidaklaziman. Dalam riset jenis ini, penulis justru perlu "membiarkan datanya berbicara terlebih dahulu", baru disandingkan dengan teori-teori (pendekatan menulis induktif). Maknanya, sesuai dengan filosofi penelitian kualitatif, penulis justru perlu mengurung terlebih dahulu segenap asumsi-asumsinya. Hal yang sering ditemukan adalah dalam "Diskusi" ("Pembahasan"), penulis sudah memiliki setumpuk asumsi di kepalanya yang kemudian dituangkan pada setiap awal paragraf pembahasan untuk dijadikan kerangka (frame) pembahasan atas data risetnya. Hal ini bertentangan dengan semangat dan intensi penelitian kualitatif.

Ada juga "Diskusi" ("Pembahasan") hasil penelitian yang mengarah pada perampatan yang keterlaluan (overgeneralization). Sebagai contoh, sebuah penelitian dilakukan pada sekelompok kecil mahasiswa di kota metropolitan Jakarta, namun demikian diulas seolah-olah sebagai hasil penelitian yang dapat diaplikasikan pada "seluruh orang Indonesia", jadi termasuk orang yang tinggal di desa. Contoh lain, ketika hasil penelitian menun- 
that the research has "refuted" a theory. Meanwhile, in reality the study conducted used far fewer data sources from the previous research. Overgeneralization only indicates a "Discussion" section that is not rooted in empirical data. Consequently, if in the "Introduction" we need to adequately understand the problems, in the "Discussion" we need to sufficiently understand the data.

In "Discussion", once again, authors should deepen the readers' understanding of the research results. For instance, if a research hypothesis suggests a positive correlation between two variables, but the results show no correlation between the variables, then the "Discussion" should begin with a conceptual and theoretical argument, using previous studies, to explain why the correlation is not found. Many authors are tempted to and fall into the trap of deflecting to "other factors" before truly arguing the potentials of the research variables. Undoubtedly, it is fair to assume and thus write that there are other variables (whether called mediators, moderators, intervening variables, third variables, etc.) yet to be researched that may have affected the results of the research. Nonetheless, if the authors immediately deflect to other variables as an excuse to unexpected findings vis-a-vis the initial hypotheses, this would make the "Discussion" seem rather irresponsible.

\section{$\mathbf{R}$ for Scientific and Current References}

The last essential section of an article is "References" ("Works Cited"). In the publication domain of psychology, we believe that most Indonesian (and international) psychological journals already refer to the citation standards of the American Psychological Association (APA; 2020). Writers may read the guidelines more carefully in the authors' guidelines provided by each journal, on the Internet, or from the official manual book of the American Psychological Association (APA). However, two things worth noting (see Table 1) for all authors when writing a journal article are: to ensure that the majority of citations come from journal articles, jukkan pertentangan dengan teori atau hasil penelitian terdahulu, hal ini diklaim sebagai hasil penelitian yang "telah meruntuhkan" sebuah teori. Padahal penelitian yang dilakukan menggunakan sumber data yang jauh lebih terbatas dari penelitian sebelumnya. Perampatan yang keterlaluan hanya akan memperlihatkan "Diskusi" ("Pembahasan") yang tidak berpijak pada data empiris. Oleh karena itu, bila dalam "Pendahuluan" kita perlu memahami masalah dengan baik, dalam "Diskusi" ("Pembahasan") kita perlu memahami data dengan baik.

Dalam "Diskusi" ("Pembahasan"), sekali lagi, penulis perlu mendalamkan hasil penelitian. Sebagai contoh, bila hipotesis penelitian menyatakan adanya korelasi positif antar dua variabel, namun ditemukan tidak ada korelasi antar variabel, maka "Diskusi" ("Pembahasan") seharusnya mulai dengan argumen konseptual dan teoretis, dengan menggunakan hasilhasil studi terdahulu, mengapa sampai korelasi tidak ditemukan. Cukup banyak penulis tergoda dan jatuh untuk memalingkan diri pada "faktor-faktor lain" sebelum sungguh-sungguh berargumen dengan menggunakan potensi variabel yang diteliti. Tentu saja, menduga bahwa ada variabel lain (entah disebut sebagai variabel mediator, moderator, intervening, variabel ketiga, dan sebagainya) yang belum diteliti mungkin telah mempengaruhi hasil penelitian merupakan hal yang sah untuk dituliskan. Kendati demikian, apabila penulis langsung berpaling pada variabel-variabel lain untuk menjadi permakluman (excuse) atas hasil penelitian yang tidak diharapkan dalam hipotesis, hal ini akan menjadikan "Diskusi" ("Pembahasan") tampak kurang bertanggung jawab.

\section{Referensi atau Pustaka Acuan yang Ilmiah dan Terkini}

Bagian terakhir yang esensial pada suatu artikel adalah "Referensi" ("Pustaka Acuan"). Dalam ranah publikasi psikologi, kami meyakini sebagian besar jurnal psikologi Indonesia (dan internasional) mengacu pada standar sitasi American Psychological Association (APA; 2020). Penulis sekalian dapat membaca panduannya dengan lebih detil pada panduan penulis di tiap-tiap jurnal, laman Internet, maupun buku manual resmi dari American Psychological Association (APA). Akan tetapi, dua hal (lihat Tabel 1) yang menjadi perhatian utama bagi penulis setiap menulis artikel jurnal adalah memastikan sumber sitasi sebagian besar berasal 
and that they come from current sources (from the past ten years, at the latest).

An analogy for a journal article is a "conversation." As researchers and authors, we want to contribute to the "conversation" already preceded by other researchers before us. To ensure the relevance of our conversation materials, we need to cite the topic, discussion, or conversation materials from previously published journals. The conversation will become even more relevant if we use the most current and non-obsolete sources. Therefore, going above and beyond the requirements (e.g., citations from journal articles and up-to-date sources), authors and journal editors should prudently evaluate: "Whether this article has cited relevant scientific sources in supporting the conversation for the area in which the research would like to contribute?"

\section{Epilogue}

TIM RaDaR is a joint effort expected to enhance the development of psychology as a scientific discipline in Indonesia. This guideline was developed based on a survey involving more than 80 editors of Indonesian psychological journals. Although no absolute agreement has been established, this result is expected to be considered as a form of agreement or consensus on what to include in scientific journals, especially in the field psychology. The prepared checklist may be used in various settings according to the needs and customs of institutions and authors. Similar guidelines on the acceptance criteria of an article may also be seen in the writing of Jaya (2020). Together with the article (Jaya, 2020), TIM RaDaR is expected to become an instrument to aid students, scholars of psychology, or would-be contributors who seek to publish in Indonesian psychological journals. In conjunction with the policies on the use of reporting guidelines in scientific journals, Roberts (2013) and Roberts et al. (2014) have also introduced a number of steps in the application of standard policies on journal management. From the proposed steps, one of the most important is the determination of enforcement level, from mandatory compliance or merely recommending the use of said guidelines. dari artikel jurnal dan merupakan referensi yang terkini (sekurang-kurangnya sepuluh tahun terakhir).

Salah satu analogi dari artikel jurnal adalah "percakapan." Sebagai peneliti dan penulis, kita ingin bergabung ke sebuah "percakapan" yang sudah dilakukan oleh peneliti-peneliti terdahulu. Supaya bahan pembicaraan kita menjadi relevan, kita perlu mengutip topik, diskusi, atau bahan percakapan dari artikel jurnal yang telah dipublikasikan sebelumnya. Percakapan akan semakin relevan ketika kita menggunakan sumber yang terkini dan belum usang. Oleh karena itu, melebihi sebuah keharusan (contoh: harus artikel jurnal dan harus terkini), penulis dan pengelola jurnal harus mengevaluasi dengan bijak-sana: "Apakah artikel ini sudah mengutip sumber-sumber ilmiah yang relevan dalam menunjang per-cakapan di area penelitian yang ingin diperbincangkan?"

\section{Epilog}

TIM RaDaR adalah suatu upaya bersama yang diharapkan membawa manfaat bagi perkembangan keilmuan psikologi di Indonesia. Panduan ini dikembangkan berdasarkan hasil survei yang melibatkan lebih dari 80 para penyunting jurnal psikologi Indonesia. Walaupun belum mencapai kesepakatan absolut, namun hasil ini dapat dianggap sebagai bentuk kesepahaman atau kemufakatan tentang apa yang seharusnya ada pada jurnal ilmiah khususnya di bidang psikologi. Daftar periksa yang dihasilkan dapat dimanfaatkan secara beragam sesuai dengan kebutuhan dan kebiasaan lembaga maupun penulis. Panduan serupa mengenai kriteria penerimaan suatu artikel juga dapat dilihat pada tulisan Jaya (2020). Bersama dengan tulisan tersebut (Jaya, 2020), TIM $\mathrm{RaDaR}$ diharapkan menjadi alat bantu yang mempermudah mahasiswa, ilmuwan psikologi, ataupun calon kontributor yang memiliki tujuan untuk melakukan publikasi pada jurnal psikologi di Indonesia. Sehubungan dengan kebijakan perihal penggunaan panduan pelaporan pada sebuah jurnal, Roberts (2013) dan Roberts et al. (2014) telah memperkenalkan sejumlah langkah dalam penerapan kebijakan standar pada pengelolaan jurnal. Dalam usulan tersebut, salah satu langkah penting adalah penentuan tingkat penegakan aturan, mulai dari kepatuhan wajib (mandatory compliance) atau hanya merekomendasikan penggunaan pedoman. 
In our journal, ANIMA Indonesian Psychological Journal, this checklist has been increasingly used to conduct screening on manuscripts received. The Faculty of Psychology of Universitas Surabaya has also gradually adopted checklist to conduct screening of scientific articles and research proposals considered worth introducing to the editors of accredited scientific journal in Indonesia. We hope that TIM $\mathrm{RaDaR}$ is also able to help fellow editors of Indonesian psychological journals to acquire articles that meet the minimum substantive criteria and help speed or ease the process of desk review.

Nevertheless, we realize that TIM RaDaR is still at its beginning stages and still warrants quality improvement in the future. For example, the TIM $\mathrm{RaDaR}$ guideline is currently still very structured and tend to favor manuscripts with quantitative approach. It is our hope that TIM RaDaR would continue to develop in order to aid authors in reporting their qualitative research more easily and much better, e.g., by integrating the recommendations on quality improvements for qualitative research in psychology as written by Lestari (2021). In addition, Table 1 is presented as brief information, rather than presenting complete and in-depth information. For instance, the information on research participants and data analysis technique may be enriched by addressing the issue of missing data or the procedures of determining the number of participants.

In the future, TIM RaDaR is hoped to present information on how to report supplementary materials, authors' contribution, conflict of interest statement, pre-registration, or the use of software for reference. The implementation of TIM RaDaR may also be extended as a tool for the publication process. For example, TIM RaDaR may be developed as an assessment tool or adjudication rubric on the quality of scientific manuscripts. This assessment may then be used by journal editors or lecturers to assess articles or scientific works.

To close, the guidelines presented in this article is hoped to become seeds of goodness that bring about positive impact for the development of scientific journal governance. The consensus among journal editors is hoped to be known, accepted, used, and developed in various organizations according to their
Pada jurnal kami sendiri, ANIMA Indonesian Psychological Journal, daftar periksa ini telah digunakan secara bertahap sebagai alat bantu untuk melakukan penyaringan (screening) naskah yang diterima. Di Fakultas Psikologi Universitas Surabaya, daftar periksa ini secara bertahap digunakan untuk melakukan screening atau penyaringan artikel dan proposal penelitian yang layak untuk diperkenalkan kepada para pengelola jurnal ilmiah terakreditasi di Indonesia. Kami juga berharap TIM RaDaR mampu membantu sesama pengelola jurnal psikologi di Indonesia untuk mendapatkan artikel yang telah memenuhi kriteria minimal secara substantif dan mempercepat atau mempermudah proses desk review.

Akan tetapi, kami menyadari bahwa TIM RaDaR masih berada pada tahap awal yang membutuhkan peningkatan mutu di masa mendatang. Sebagai contoh, panduan TIM RaDaR masih sangat terstruktur dan condong pada tulisan yang menggunakan pendekatan kuantitatif. Kami berharap TIM RaDaR dapat terus berkembang untuk membantu penulis melaporkan hasil penelitian kualitatif dengan lebih mudah dan baik, misal melalui integrasi terhadap rekomendasi peningkatan mutu riset kualitatif psikologi Indonesia yang ditulis oleh Lestari (2021). Selain itu, Tabel 1, yang ditujukan sebagai informasi ringkas, belum menampilkan informasi secara mendalam atau menyeluruh. Misalnya, informasi tentang partisipan penelitian dan teknik analisis data dapat diperkaya dengan cara mengatasi missing data atau cara menentukan jumlah partisipan.

TIM RaDaR di masa mendatang dapat menampilkan informasi cara melaporkan data pendamping (supplementary materials), kontribusi penulis, pernyataan bebas konflik kepentingan, pre-registrasi, atau penggunaan peranti lunak untuk referensi. Implementasi TIM RaDaR juga dapat diperluas sebagai alat bantu proses publikasi. Contohnya, TIM RaDaR dapat dikembangkan menjadi alat asesmen atau rubrik penilaian mutu suatu karya tulis. Alat asesmen kemudian dapat dipakai oleh pengelola jurnal atau dosen pengajar untuk menilai suatu artikel atau karya tulis.

Sebagai penutup, panduan yang ada ini diharapkan dapat menjadi benih-benih kebaikan yang menumbuhkan dampak positif dalam pengembangan tata kelola jurnal ilmiah. Hasil kemufakatan di antara para pengelola jurnal ini diharapkan dapat diketahui, diterima, digunakan, dan dikembangkan di berbagai 
respective needs and conditions. Actively involved scholars are hoped to become pioneers, disseminators of inspiration, and spreader of positive spirit to continually revise and use the presented checklist, in order to improve the quantity and quality of publication in their respective institutions. In the spirit of sustainability, it is hoped that various innovative products and services would emerge in improving the access and readiness of the checklist to help the management of scientific publications, from the discipline of psychology and from Indonesia. This checklist may be used openly by citing adequate contribution to the Formulating Team to be further recognized as the pioneers of TIM RaDaR.

\section{Conflict of Interest Statement}

All authors declare that the article was prepared in the absence of any commercial or financial relationships that could be construed as a potential conflict of interest. lembaga sesuai kebutuhan dan kondisi masing-masing. Para cendekiawan yang terlibat aktif diharapkan dapat menjadi pelopor, penyebar inspirasi, dan pengobar semangat positif untuk terus memperbaiki dan menggunakan daftar periksa yang ada untuk meningkatkan kuantitas dan kualitas publikasi di lembaga masingmasing. Secara berkelanjutan diharapkan, muncul beragam inovasi produk dan layanan meningkatkan akses dan kesiap-terapan daftar periksa ini guna membantu pengelolaan publikasi ilmiah, berawal dari disiplin ilmu psikologi dan bermula dari Indonesia. Daftar periksa ini dapat digunakan dengan bebas dengan memberikan kontribusi yang memadai pada Tim Perumus yang untuk selanjutnya diperkenalkan atau dikenang sebagai penggagas-pelopor TIM RaDaR.

\section{Pernyataan Konflik Kepentingan}

Semua penulis menyatakan bahwa artikel ini ditulis dengan tanpa adanya relasi komersil atau finansial yang dapat berfungsi sebagai potensi konflik kepentingan.

\section{References}

Abraham, J. (2021). Ethical clearance: Untuk apa dan oleh siapa? [Ethical clearance: For what and whom?] [PowerPoint slides]. Universitas Bina Nusantara - SlideShare.

https://bit.ly/etikariset

American Psychological Association [APA]. (2020). Publication manual of the American Psychological Association (7th ed.). Author. https://doi.org/10.1037/0000165-000

American Psychological Association [APA] Publications and Communications Board Working Group on Journal Article Reporting Standards [JARS]. (2008). Reporting standards for research in psychology: Why do we need them? What might they be? American Psychologist, 63(9), 839-851.

https://doi.org/10.1037/0003-066X.63.9.839

American Society of Civil Engineers [ASCE]. (2019). State-of-the-art review proposal guidelines. American Society of Civil Engineers (ASCE) Library.

https://ascelibrary.org/doi/10.1061/9780784479018.ap01

Appelbaum, M., Cooper, H., Kline, R. B., Mayo-Wilson, E., Nezu, A. M., \& Rao, S. M. (2018). Journal Article Reporting Standards for quantitative research in psychology: The APA Publications and Communications Board Task Force report. American Psychologist, 73(1), 3-25.

https://doi.org/10.1037/amp0000191

Armağan, A. (2013). How to write an introduction section of a scientific article? Turkish Journal of Urology, 39(Supplement 1), 8-9. https://doi.org/10.5152/tud.2013.046

Ball, P. (2002). Paper trail reveals references go unread by citing authors. Nature, 420(6916), 594-594. https://doi.org/10.1038/420594a

Bavdekar, S. B. (2016). Formulating the right title for a research. Journal of The Association of Physicians of India, 64(2), 53-56.

https://www.japi.org/q2d4b4b4/formulating-the-right-title-for-a-research-article 
Belcher, W. L. (2019). Writing your journal article in twelve weeks: A guide to academic publishing success (2nd ed.). The University of Chicago Press.

https://press.uchicago.edu/ucp/books/book/chicago/W/bo26985005.html

Beleslin, I., Njegovan, B. R., \& Vukadinović, M. S. (2017, October). Clickbait titles: Risky formula for attracting readers and advertisers. Proceedings of the XVII (17th) International Scientific Conference on Industrial Systems (IS'17), 364-369.

https://www.iim.ftn.uns.ac.rs/is17/papers/65.pdf

Cooper, H. (2020). Reporting quantitative research in psychology: How to meet APA Style Journal Article Reporting Standards (2nd ed.). American Psychological Association. https://doi.org/10.1037/0000178-000

Elliott, R., Fischer, C. T., \& Rennie, D. L. (1999). Evolving guidelines for publication of qualitative research studies in psychology and related fields. British Journal of Clinical Psychology, 38(3), 215-229. https://doi.org/10.1348/014466599162782 https://bpspsychub.onlinelibrary.wiley.com/doi/10.1348/014466599162782

Ellis, T. J., \& Levy, Y. (2008). Framework of problem-based research: A guide for novice researchers on the development of a research-worthy problem. Informing Science: The International Journal of an Emerging Transdiscipline, 11, 17-33. https://doi.org/10.28945/438

EQUATOR Network. (n.d.) Reporting guidelines. EQUATOR Network. https://www.equator-network.org/reporting-guidelines/

Fakultas Psikologi Universitas Surabaya. (2020). Hasil survei standar publikasi ilmiah [Data set]. Universitas Surabaya. https://s.id/survei-standar-publikasi-psikologi-indonesia

Gray, J. A. (2019). Paragraphs in medical writing. AME Medical Journal (AMJ), 4:28, 1-7. https://doi.org/10.21037/amj.2019.05.02

Guillemard, M. (2017). Three strategies to help you write clearly for a lay audience. Medical Writing, 26(1), 35-37.

https://journal.emwa.org/writing-better/three-strategies-to-help-you-write-clearly-for-a-lay-audience/

Harzing, A. -W. \& Kroonenberg, P. (2017). The mystery of the phantom reference. Harzing.com: Research in International Management.

https://harzing.com/publications/white-papers/the-mystery-of-the-phantom-reference

Jacso, P. (2006). Deflated, inflated and phantom citation counts. Online Information Review, 30(3), 297-309. https://doi.org/10.1108/14684520610675816

Jaya, E. S. (2020). Editorial note: How do we evaluate your manuscript? Makara Human Behavior Studies in Asia (Makara Hubs-Asia), 24(2), 99-100.

https://doi.org/10.7454/hubs.asia.1311220

Kazak, A. E. (2018). Editorial: Journal Article Reporting Standards. American Psychologist, 73(1), 1-2. https://doi.org/10.1037/amp0000263

Ke, Q., Ferrara, E., Radicchi, F., \& Flammini, A. (2015). Defining and identifying Sleeping Beauties in science. Proceedings of the National Academy of Sciences (PNAS) of the United States of America, 112(24), 7426-7431. https://doi.org/10.1073/pnas.1424329112

Lange, L. L. (2005). Sleeping Beauties in psychology: Comparisons of "hits" and "missed signals" in psychological journals. History of Psychology, 8(2), 194-217. https://doi.org/10.1037/1093-4510.8.2.194

Larsson, K. S. (1995). The dissemination of false data through inadequate citation. Journal of Internal Medicine (JIM), 238(5), 445-450. https://doi.org/10.1111/j.1365-2796.1995.tb01222.x

Leng, R. (2020). Citation distortion. The Matter of Facts. https://www.the-matter-of-facts.com/post/citation-and-the-distortion-of-meaning

Lestari, M. D. (2021). "More than just a verbatim": Enhancing the quality of Indonesian psychological qualitative studies. Jurnal Psikologi Ulayat: Indonesian Journal of Indigenous Psychology, 8(1), 1-5. 
https://doi.org/10.24854/jpu481

Lester, J. D., \& Lester J. D., Jr. (2015). Writing research papers: A complete guide (15th ed.). Pearson. https:/www.pearson.com/us/higher-education/product/Lester-Writing-Research-Papers-A-CompleteGuide-paperback-15th-Edition/9780321952950.html

Levitt, H. M., Bamberg, M., Creswell, J. W., Frost, D. M., Josselson, R., \& Suárez-Orozco, C. (2018). Journal Article Reporting Standards for qualitative primary, qualitative meta-analytic, and mixed methods research in psychology: The APA Publications and Communications Board Task Force report. American Psychologist, 73(1), 26-46.

https://doi.org/10.1037/amp0000151

Levitt, H. M. (2020). Reporting qualitative research in psychology: How to meet APA Style Journal Article Reporting Standards (Revised Edition). American Psychological Association. https://doi.org/10.1037/0000179-000

Lingard, L., \& Watling, C. (2016). It's a story, not a study: Writing an effective research paper. Academic Medicine: Journal of the Association of American Medical Colleges, 91(12), e12. https://doi.org/10.1097/ACM.0000000000001389

Page, M. J., Moher, D., Bossuyt, P. M., Boutron, I., Hoffmann, T. C., Mulrow, C. D., Shamseer, L., Tetzlaff, J. M., Akl, E. A., Brennan, S. E., Chou, R., Glanville, J., Grimshaw, J. M., Hróbjartsson, A., Lalu, M. M., Li, T., Loder, E. W., Mayo-Wilson, E., Mcdonald, S., McGuinness, L. A., Stewart, L. A., Thomas, J., Tricco, A. C., Welch, V. A., Whiting, P., Mckenzie, J. E. (2021). PRISMA 2020 explanation and elaboration: Updated guidance and exemplars for reporting systematic reviews. British Medical Journal (BMJ), 372, n160.

https://doi.org/10.1136/bmj.n160

Roberts, J. (2013). Developing and implementing a reporting guidelines policy: Notes from a small journal. EQUATOR Network.

https://www.equator-network.org/wp-content/uploads/2013/08/EQUATOR-Workshop-Short-

Presentation.pdf

Roberts, J. L., Houle, T. T., Loder, E. W., Penzien, D. B., Turner, D. P., \& Rothrock, J. F. (2014). Establishing a coherent reporting guidelines policy in health journals. In D. Moher, D. G. Altman, K. F. Schulz, I. Simera, \& E. Wager (Eds.), Guidelines for reporting health research: A user's manual (1st ed.) (pp. 309-317). John Wiley \& Sons, Ltd. https://doi.org/10.1002/9781118715598.ch29

Schulz, K., Altman, D., \& Moher, D. (2010a). CONSORT 2010 Statement: Updated guidelines for reporting parallel group randomised trials [Correspondence]. BioMed Central (BMC) Medicine, 8, 18. https://doi.org/10.1186/1741-7015-8-18

Schulz, K., Altman, D., \& Moher, D. (2010b). CONSORT 2010 Statement: Updated guidelines for reporting parallel group randomised trials [Research Method and Reporting]. British Medical Journal (BMJ), 340, c332.

https://doi.org/10.1136/bmj.c332

Shamseer, L., Moher, D., Clarke, M., Ghersi, D., Liberati, A., Petticrew, M., Shekelle, P., Stewart, L. A., The PRISMA-P Group. (2015). Preferred Reporting Items for Systematic Review and Meta-Analysis Protocols (PRISMA-P) 2015: Elaboration and explanation. British Medical Journal (BMJ), 349, g7647. https://doi.org/10.1136/bmj.g7647

Siaputra, I. B., Abraham, J., \& Lukman, L. (2019). ANJANI (Anjungan Integritas Akademik Indonesia): Kolaborasi nasional meningkatkan integritas akademik [Indonesian Academic Integrity Platform: National collaboration in increasing academic integrity] [PowerPoint slides]. Universitas Surabaya DocPlayer. https://bit.ly/anjanisosialisasi

Simkin, M. V., \& Roychowdhury, V. P. (2002). Read before you cite! Cornell University - arXiv.org. https://arxiv.org/abs/cond-mat/0212043

Simkin, M. V., \& Roychowdhury, V. P. (2006). Do you sincerely want to be cited? Or: Read before you cite. Significance, 3(4), 179-181. https://doi.org/10.1111/j.1740-9713.2006.00202.x 
Stang, A. (2010). Critical evaluation of the Newcastle-Ottawa Scale for the assessment of the quality of nonrandomized studies in meta-analyses. European Journal of Epidemiology, 25(9), 603-605. https://doi.org/10.1007/s10654-010-9491-z

Stang, A., Jonas, S., \& Poole, C. (2018). Case study in major quotation errors: A critical commentary on the Newcastle-Ottawa Scale. European Journal of Epidemiology, 33(11), 1025-1031. https://doi.org/10.1007/s10654-018-0443-3

Steel, C. M. (1996). Read before you cite. The Lancet, 348(9021), 144. https://doi.org/10.1016/S0140-6736(05)66108-9

Stevens, J. R. (2017). Replicability and reproducibility in comparative psychology. Frontiers in Psychology, $8: 862$. https://doi.org/10.3389/fpsyg.2017.00862

Taylor \& Francis Author Services. (2020). How to write a journal article. Taylor \& Francis Online. https://authorservices.taylorandfrancis.com/writing-a-journal-article/

Tullu, M. S. (2019). Writing the title and abstract for a research paper: Being concise, precise, and meticulous is the key. Saudi Journal of Anaesthesia, 13(5), 12-17. https://doi.org/10.4103/sja.SJA_685_18

University of Washington. (n.d.). Writing effective purpose statements. University of Washington Web Server.

https://faculty.washington.edu/ezent/imwps.htm

van Raan, A. F. J. (2004). Sleeping Beauties in science. Scientometrics, 59(3), 467-472. https://doi.org/10.1023/b:scie.0000018543.82441.f1

von Elm, E., Altman, D. G., Egger, M., Pocock, S. J., Gøtzsche, P. C., \& Vandenbroucke, J. P. (2007). The Strengthening the Reporting of Observational Studies in Epidemiology (STROBE) Statement: Guidelines for reporting observational studies. Epidemiology, 18(6), 800-804.

https://doi.org/10.1097/EDE.0b013e3181577654 


\section{Appendix A}

Supplementary materials can be accessed through: | Materi pendukung dapat diakses melalui: https://s.id/survei-standar-publikasi-psikologi-indonesia

How to cite the supplementary materials: | Cara menyitat materi pendukung:

Fakultas Psikologi Universitas Surabaya. (2020). Hasil survei standar publikasi ilmiah [Dataset]. https://s.id/survei-standar-publikasi-psikologi-indonesia

\section{Appendix B}

Table 2 | Tabel 2

List of Contributors $\mid$ Daftar Kontributor

\begin{tabular}{|c|c|c|c|c|c|c|c|c|}
\hline No. & Name | Nama & Participation | Partisipasi & Journal or Affiliation | Jurnal atau Afiliasi & $\mathrm{A}$ & B & \begin{tabular}{l|l}
$\mathrm{C}$ & $\mathrm{I}$ \\
\end{tabular} & \begin{tabular}{l|l}
$\mathrm{D}$ & $\mathrm{E}$ \\
\end{tabular} & $\mathrm{F}$ \\
\hline 1 & Abigail Soesana & 3 & Universitas Surabaya & & $\sqrt{ }$ & $\sqrt{ }$ & $\sqrt{ }$ & \\
\hline 2 & Ade Hidayat & 5 & Indonesian Journal of Educational Counseling & & $\sqrt{ }$ & $\sqrt{ }$ & $\sqrt{ }$ & $\sqrt{ }$ \\
\hline 3 & Agung Iranda & 2 & Universitas Jambi & & $\sqrt{ }$ & $\sqrt{ }$ & & \\
\hline 4 & Alfina Gustiany & 1 & Analitika: Jurnal Magister Psikologi UMA & $\sqrt{ }$ & & & & \\
\hline 5 & Ali Ridho & 3 & Psikoislamika: Jurnal Psikologi dan Psikologi Islam & $\sqrt{ }$ & $\sqrt{ }$ & $\sqrt{ }$ & & \\
\hline 6 & Alifah Nabilah Masturah & 5 & Jurnal Ilmiah Psikologi Terapan & & $\sqrt{ }$ & $\sqrt{ }$ & $\sqrt{ }$ & $\sqrt{ }$ \\
\hline 7 & Amatul Firdausa Nasa & 1 & Jurnal Ilmu Perilaku & $\sqrt{ }$ & & & & \\
\hline 8 & Andrian Pramadi & 2 & Universitas Surabaya & & & 1 & $\sqrt{ }$ & \\
\hline 9 & Anissa Lestari & 3 & Journal of Psychological Science and Profession & $\sqrt{ }$ & $\sqrt{ }$ & $\sqrt{ }$ & & \\
\hline 10 & Ardiningtiyas Pitaloka & 1 & $\begin{array}{l}\text { Jurnal Psikologi Ulayat: Indonesian Journal of Indigenous } \\
\text { Psychology }\end{array}$ & $\sqrt{ }$ & & & & \\
\hline 11 & Baidi Bukhori & 5 & Psikohumaniora: Jurnal Penelitian Psikologi & $\sqrt{ }$ & $\sqrt{ }$ & $\sqrt{ }$ & $\sqrt{ }$ & $\sqrt{ }$ \\
\hline 12 & Bartolomeus Yofana Adiwena & 3 & Psikodimensia & & & & $\sqrt{ }$ & $\sqrt{1}$ \\
\hline 13 & Bidayatul Hidayah & 1 & Jurnal Psikologi Sosial & $\sqrt{ }$ & 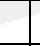 & & & \\
\hline 14 & Binta Mu'tiya Rizki & 2 & INTUISI: Jurnal Psikologi Ilmiah & & $\sqrt{ }$ & $\sqrt{ }$ & & \\
\hline 15 & Corina & 4 & Makara Hubs-Asia (Human Behavior Studies in Asia) & & $\sqrt{ }$ & $\sqrt{ }$ & $\sqrt{ }$ & $\sqrt{ }$ \\
\hline 16 & Danan Satriyo Wibowo & 5 & Jurnal Pemikiran dan Penelitian Psikologi Insight & & $\sqrt{ }$ & $\sqrt{ }$ & $\sqrt{ }$ & $\sqrt{ }$ \\
\hline 17 & Dedy Suhendra & 3 & $\begin{array}{l}\text { Jurnal Ilmiah Muqoddimah: Jurnal Ilmu Sosial, Politik, } \\
\text { dan Humaniora }\end{array}$ & & $\sqrt{ }$ & $\sqrt{ }$ & $\sqrt{ }$ & \\
\hline 18 & Dedy Surya & 5 & INSPIRA: Indonesian Journal of Psychological Research & & $\sqrt{ }$ & $\sqrt{ }$ & $\sqrt{ }$ & $\sqrt{ } \sqrt{ }$ \\
\hline 19 & Dewi Nurnindyah & 2 & Dinas Psikologi TNI Angkatan Laut (Dispsial) & & $\sqrt{ }$ & $\sqrt{ }$ & & \\
\hline 20 & Dhian Riskiana Putri & 3 & Jurnal Talenta & & $\sqrt{ }$ & $\sqrt{ }$ & $\sqrt{ }$ & \\
\hline 21 & Dian Ekawati & 2 & Humanitas: Indonesian Psychological Journal & & $\sqrt{ }$ & $\sqrt{ }$ & & \\
\hline 22 & Dwi Hurriyati & 5 & Jurnal Ilmiah Psyche & & $\sqrt{ }$ & $\sqrt{ }$ & $\sqrt{ }$ & $\sqrt{ }$ \\
\hline 23 & Edo Sebastian Jaya & 3 & Makara Hubs-Asia (Human Behavior Studies in Asia) & $\sqrt{ }$ & $\sqrt{ }$ & $\sqrt{ }$ & & \\
\hline 24 & Edwin Adrianta Surijah & 4 & ANIMA Indonesian Psychological Journal & & $\sqrt{ }$ & $\sqrt{ }$ & $\sqrt{ }$ & $\sqrt{ }$ \\
\hline 25 & Eko Susanto & 3 & $\begin{array}{l}\text { GUIDENA: Jurnal Ilmu Pendidikan, Psikologi, } \\
\text { Bimbingan dan Konseling }\end{array}$ & $\sqrt{ }$ & $\sqrt{ }$ & $\sqrt{ }$ & & \\
\hline 26 & Ersa L. S. & 2 & Psychopreneur & & $\sqrt{ }$ & $\sqrt{ }$ & & \\
\hline 27 & Erwin Erlangga & 1 & Fakultas Psikologi Universitas Semarang & & & & $\sqrt{ }$ & \\
\hline 28 & Etti Rahmawati & 1 & Universitas Sumatera Utara & & & & $\sqrt{ }$ & \\
\hline 29 & Faraz & 1 & Jurnal Intervensi Psikologi (JIP) & $\sqrt{ }$ & & & & \\
\hline 30 & Farida Coralia & 5 & Schema Journal of Psychological Research & & $\sqrt{ }$ & $\sqrt{ }$ & $\sqrt{ }$ & $\sqrt{ }$ \\
\hline 31 & Feri Faila sufa & 5 & AUDI & & $\sqrt{ }$ & $\sqrt{ }$ & $\sqrt{ }$ & \\
\hline 32 & Fitri Ayu Kusumaningrum & 1 & Psikologika : Jurnal Pemikiran dan Penelitian Psikologi & $\sqrt{ }$ & & & & \\
\hline 33 & Galang Lufityanto & 3 & Buletin Psikologi & $\sqrt{ }$ & $\sqrt{ }$ & $\sqrt{ }$ & & \\
\hline 34 & Garvin Goei & 2 & Psibernetika & & $\sqrt{ }$ & $\sqrt{ }$ & & \\
\hline
\end{tabular}

(Appendix continues) 


\begin{tabular}{|c|c|c|c|c|c|c|c|c|c|}
\hline No. & Name | Nama & Participation | Partisipasi & Journal or Affiliation | Jurnal atau Afiliasi & $\mathrm{A}$ & $\mathrm{B}$ & $\mathrm{C}$ & $\mathrm{D}-1$ & & $\mathrm{~F}$ \\
\hline 35 & Hafnidar & 2 & Universitas Malikussaleh & & $\sqrt{ }$ & $\sqrt{ }$ & & & \\
\hline 36 & Handrix Chris Haryanto & 2 & INQUIRY: Jurnal Ilmiah Psikologi & & $\sqrt{ }$ & $\sqrt{ }$ & & & \\
\hline 37 & Hari Santoso & 1 & Fakultas Psikologi UIN Ar Raniry & & & & $\sqrt{ }$ & & \\
\hline 38 & Harri Santoso & 4 & Psikoislamedia Jurnal Psikologi & $\sqrt{ }$ & $\sqrt{ }$ & $\sqrt{ }$ & $\sqrt{ }$ & & \\
\hline 39 & Helmi Suyanto & 1 & Psikohumaniora: Jurnal Penelitian Psikologi & & & & $\sqrt{ }$ & & \\
\hline 40 & Herdiyan Maulana & 1 & Jurnal Penelitian dan Pengukuran Psikologi: JPPP & $\sqrt{ }$ & & & & & \\
\hline 41 & Herlina Siwi Widiana & 5 & Humanitas: Indonesian Psychological Journal & & $\sqrt{ }$ & $\sqrt{ }$ & $\sqrt{ }$ & $\sqrt{ }$ & $\sqrt{1}$ \\
\hline 42 & I Gusti Agung Ananda Giri Nugraha & 2 & Jurnal Psikologi Udayana & $\sqrt{ }$ & & & $\sqrt{ }$ & & \\
\hline 43 & I Putu Mas Dewantara & 5 & $\begin{array}{l}\text { Jurnal Penelitian dan Pengembangan Sains dan } \\
\text { Humaniora }\end{array}$ & & $\sqrt{ }$ & $\sqrt{ }$ & $\sqrt{ }$ & $\sqrt{ }$ & $\sqrt{1}$ \\
\hline 44 & Ide Bagus Siaputra & 4 & Universitas Surabaya & $\sqrt{ }$ & $\sqrt{ }$ & & $\sqrt{ }$ & $\sqrt{ }$ & \\
\hline 45 & Ila Nurlaila Hidayat & 3 & JPIB: Jurnal Psikologi Islam dan Budaya & $\sqrt{ }$ & $\sqrt{ }$ & $\sqrt{ }$ & & & \\
\hline 46 & Ilham Khairi Siregar & 2 & Biblio Couns: Jurnal Kajian Konseling dan Pendidikan & & $\sqrt{ }$ & $\sqrt{ }$ & & & \\
\hline 47 & Imadduddin & 2 & Jurnal Studia Insania & & $\sqrt{ }$ & $\sqrt{ }$ & & & \\
\hline 48 & Imam Faisal Hamzah & 6 & Jurnal Ilmiah Psikologi : Psycho Idea & $\sqrt{ }$ & $\sqrt{ }$ & $\sqrt{ }$ & $\sqrt{ }$ & & $\sqrt{ }$ \\
\hline 49 & Iqmal Tahir & 2 & Pusat Studi Lingkungan Hidup UGM & & $\sqrt{ }$ & $\sqrt{ }$ & & & \\
\hline 50 & Iredho Fani Reza & 3 & PSIKIS: Jurnal Psikologi Islami & $\sqrt{ }$ & $\sqrt{ }$ & $\sqrt{ }$ & & & \\
\hline 51 & Joevarian Hudiyana & 3 & Jurnal Psikologi Sosial & $\sqrt{ }$ & $\sqrt{ }$ & $\sqrt{ }$ & & & \\
\hline 52 & Juneman Abraham & 3 & ANIMA Indonesian Psychological Journal & & & & $\sqrt{ }$ & & $\sqrt{ }$ \\
\hline 53 & Karel Himawan & 3 & $\begin{array}{l}\text { Jurnal Psikologi Ulayat: Indonesian Journal of Indigenous } \\
\text { Psychology }\end{array}$ & $\sqrt{ }$ & $\sqrt{ }$ & $\sqrt{ }$ & & & \\
\hline 54 & Khairani Zikrinawati & 2 & Psikohumaniora: Jurnal Penelitian Psikologi & & & & $\sqrt{ }$ & & $\sqrt{1}$ \\
\hline 55 & Laila & 3 & Universitas Mercu Buana Jakarta & & $\sqrt{ }$ & $\sqrt{ }$ & $\sqrt{ }$ & & \\
\hline 56 & Layyinah, S.Psi., M.Si & 1 & $\begin{array}{l}\text { Jurnal Pengukuran Psikologi dan Pendidikan Indonesia } \\
\text { (JP3I) }\end{array}$ & $\sqrt{ }$ & & & & & \\
\hline 57 & Listiyani & 2 & Prodi Psikologi Universitas Dhyana Pura & & $\sqrt{ }$ & $\sqrt{ }$ & & & \\
\hline 58 & M. Arif Khoiruddin & 1 & Journal An-Nafs: Kajian Penelitian Psikologi & $\sqrt{ }$ & 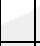 & & & & \\
\hline 59 & Mafaza & 5 & Jurnal Ilmu Perilaku & $\sqrt{ }$ & $\sqrt{ }$ & $\sqrt{ }$ & $\sqrt{ }$ & $\sqrt{ }$ & \\
\hline 60 & Maria Helena Suprapto & 3 & Jurnal Gema Aktualita & & $\sqrt{ }$ & $\sqrt{ }$ & & & $\sqrt{ }$ \\
\hline 61 & Melok Roro Kinanthi & 2 & Jurnal Psikogenesis & & $\sqrt{ }$ & $\sqrt{ }$ & & & \\
\hline 62 & Missiliana R & 2 & Humanitas (Jurnal Psikologi) & Le & $\sqrt{ }$ & $\sqrt{ }$ & & & \\
\hline 63 & Mochamad Alfian & 1 & Psikologia (Jurnal Psikologi) & $\sqrt{ }$ & 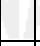 & 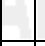 & 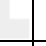 & & \\
\hline 64 & Muhammad Abdan Shadiqi & 6 & Makara Hubs-Asia (Human Behavior Studies in Asia) & $\sqrt{ }$ & $\sqrt{ }$ & $\sqrt{ }$ & $\sqrt{ }$ & $\sqrt{ }$ & $\sqrt{ }$ \\
\hline 65 & Muhammad Ali Adriansyah & 2 & Psikostudia: Jurnal Psikologi & & $\sqrt{ }$ & $\sqrt{ }$ & & & \\
\hline 66 & Muhammad Ridwan & 2 & $\begin{array}{l}\text { Budapest International Research and Critics Institute } \\
\text { (BIRCI-Journal): Humanities and Social Sciences }\end{array}$ & & $\sqrt{ }$ & $\sqrt{ }$ & & & \\
\hline 67 & Nadya AHN & 2 & Psikohumaniora: Jurnal Penelitian Psikologi & & & & $\sqrt{ }$ & & $\sqrt{1}$ \\
\hline 68 & Novendawati Wahyu Sitasari & 3 & Jurnal Psikologi: Media Ilmiah Psikologi & $\sqrt{ }$ & $\sqrt{ }$ & $\sqrt{ }$ & & & \\
\hline 69 & Novia Solichah & 6 & Psikoislamika: Jurnal Psikologi dan Psikologi Islam & $\sqrt{ }$ & $\sqrt{ }$ & $\sqrt{ }$ & $\sqrt{ }$ & & $\sqrt{ }$ \\
\hline 70 & Nur'aini Azizah & 1 & JPIB: Jurnal Psikologi Islam dan Budaya & $\sqrt{ }$ & & & & & \\
\hline 71 & Nurhasanah Purba & 1 & $\begin{array}{l}\text { Budapest International Research and Critics Institute } \\
\text { (BIRCI-Journal): Humanities and Social Sciences }\end{array}$ & & & & $\sqrt{ }$ & & \\
\hline 72 & Nurul Aiyuda & 1 & Psychopolytan: Jurnal Psikologi & $\sqrt{ }$ & & & & & \\
\hline 73 & Nurul Hidayati & 5 & Humanistis ' 45 & & $\sqrt{ }$ & $\sqrt{ }$ & $\sqrt{ }$ & $\sqrt{ }$ & $\sqrt{ }$ \\
\hline 74 & Omar K. Burhan & 1 & Universitas Sumatera Utara & & & & $\sqrt{ }$ & & \\
\hline 75 & Panca Kursistin Handayani & 2 & Insight Jurnal Penelitian dan Pemikiran Psikologi & & $\sqrt{ }$ & $\sqrt{ }$ & & & \\
\hline 76 & Putu Nugrahaeni Widiasavitri & 4 & Jurnal Psikologi Udayana & $\sqrt{ }$ & $\sqrt{ }$ & $\sqrt{ }$ & $\sqrt{ }$ & & \\
\hline 77 & Rafael Lisinus & 2 & Psikologi dan Konseling & & $\sqrt{ }$ & $\sqrt{ }$ & & & \\
\hline 78 & Ramon Ananda Paryontri & 1 & Psikologia (Jurnal Psikologi) & $\sqrt{ }$ & & & & & \\
\hline 79 & Ria Wiyatfi Linsiya & 1 & Jurnal Pemikiran dan Penelitian Psikologi Insight & $\sqrt{ }$ & & & & & \\
\hline 80 & Riana Sahrani & 5 & Provitae Jurnal Psikologi Pendidikan & & $\sqrt{ }$ & $\sqrt{ }$ & $\sqrt{ }$ & & $\sqrt{ }$ \\
\hline 81 & Rifa Hidayah & 1 & Universitas Islam Negeri Maulana Malik Ibrahim Malang & & & & $\sqrt{ }$ & & \\
\hline
\end{tabular}




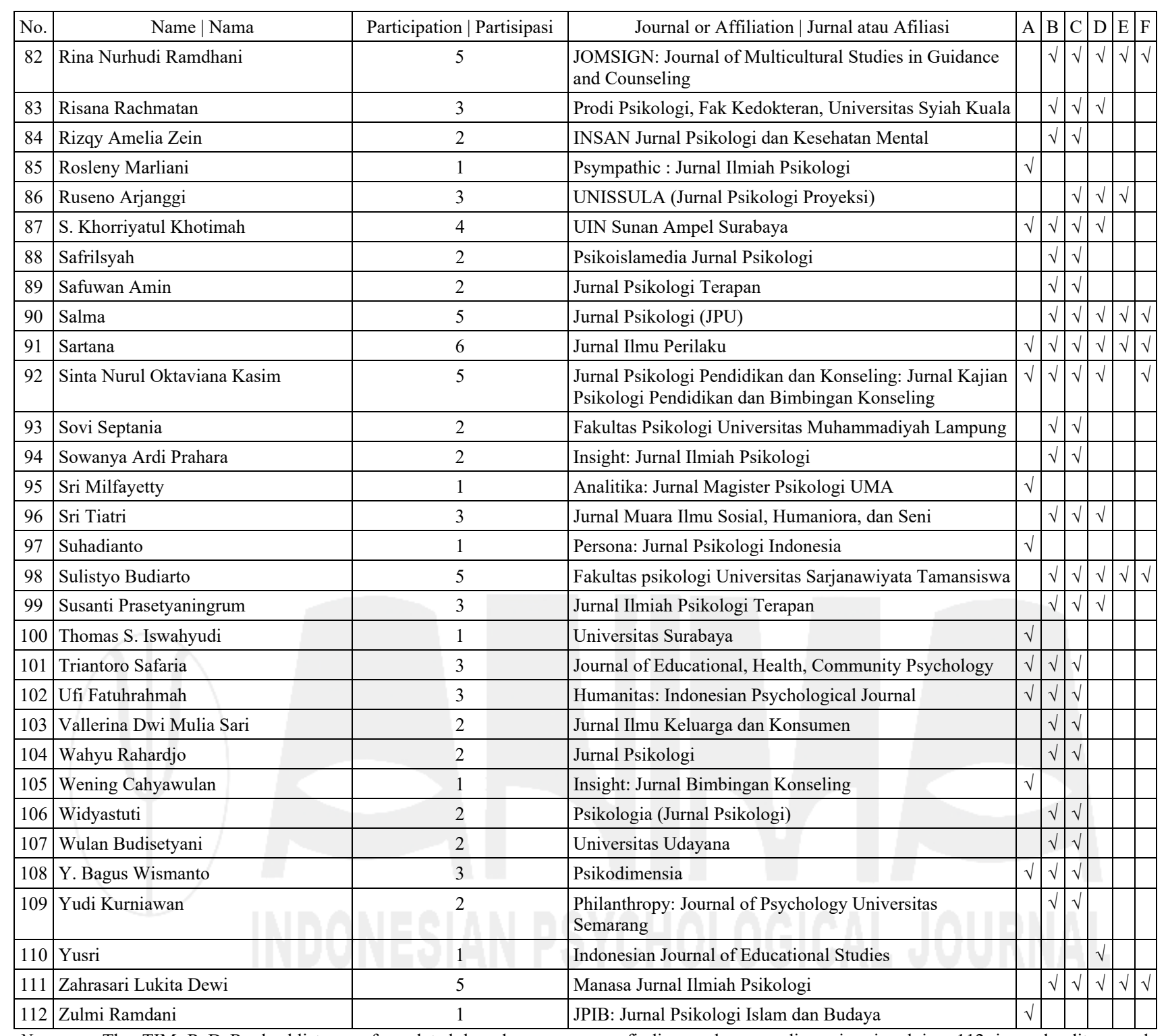

Note. The TIM RaDaR checklist was formulated based on a survey finding and group discussion involving 112 journal editors and psychological scholars from 85 journals and/or institutions; $\mathrm{A}=$ initial meeting; $\mathrm{B}=$ completed the survey; $\mathrm{C}=$ symposium registration; $\mathrm{D}$ $=$ symposium registration; $\mathrm{E}=$ screener simulation; $\mathrm{F}=$ screener decision.

Catatan. Daftar periksa TIM RaDaR disusun berdasarkan hasil survei dan diskusi kelompok yang melibatkan 112 pengelola jurnal dan para ilmuwan psikologi dari 85 jurnal dan/atau lembaga; $\mathrm{A}=$ pertemuan awal; $\mathrm{B}=$ mengisi survei; $\mathrm{C}=$ pendaftaran simposium; $\mathrm{D}=$ kehadiran simposium; $\mathrm{E}=$ simulasi screener; $\mathrm{F}=$ keputusan screener. 